\title{
The Distribution of Nickel in the
} West-Atlantic Ocean, Its Relationship With Phosphate and a Comparison to Cadmium and Zinc

\author{
Rob Middag ${ }^{1 *}$, Hein J. W. de Baar ${ }^{1,2}$, Kenneth W. Bruland ${ }^{3}$ and \\ Steven M. A. C. van Heuven ${ }^{4}$
}

\begin{abstract}
'Department of Ocean Systems (OCS), NIOZ Royal Netherlands Institute for Sea Research and Utrecht University, Texel, Netherlands, ${ }^{2}$ Department Ocean Ecosystems, University of Groningen, Groningen, Netherlands, ${ }^{3}$ Department of Ocean Sciences, Institute of Marine Sciences, University of California, Santa Cruz, Santa Cruz, CA, United States, ${ }^{4}$ Energy and Sustainability Research Institute Groningen, University of Groningen, Groningen, Netherlands
\end{abstract}

\section{OPEN ACCESS}

Edited by:

Antonio Tovar-Sanchez,

Spanish National Research Council,

Spain

Reviewed by:

Peter Croot,

National University of Ireland Galway,

Ireland

Francisco Delgadillo-Hinojosa, Autonomous University of Baja California, Mexico

*Correspondence:

Rob Middag rob.middag@nioz.nl

Specialty section: This article was submitted to Marine Biogeochemistry, a section of the journal Frontiers in Marine Science

Received: 24 October 2019 Accepted: 10 February 2020

Published: 03 March 2020

Citation:

Middag R, de Baar HJW, Bruland KW and van Heuven SMAC (2020) The Distribution of Nickel in the West-Atlantic Ocean, Its

Relationship With Phosphate and a Comparison to Cadmium and Zinc. Front. Mar. Sci. 7:105. doi: 10.3389/fmars.2020.00105
Nickel (Ni) is a bio-essential element required for the growth of phytoplankton. It is the least studied bio-essential element, mainly because surface ocean $\mathrm{Ni}$ concentrations are never fully depleted and $\mathrm{Ni}$ is not generally considered to be a limiting factor. However, stimulation of growth after $\mathrm{Ni}$ addition has been observed in past experiments when seemingly ample ambient dissolved $\mathrm{Ni}$ was present, suggesting not all dissolved $\mathrm{Ni}$ is bio-available. This study details the distribution of Ni along the GEOTRACES GA02 Atlantic Meridional section. Concentrations of $\mathrm{Ni}$ were lowest in the surface ocean and the lowest observed concentration of $1.7 \mathrm{nmol} \mathrm{kg}^{-1}$ was found in the northern hemisphere $(\mathrm{NH})$. The generally lower surface concentrations in the $\mathrm{NH}$ subtropical gyre compared to the southern hemisphere $(\mathrm{SH})$, might be related to a greater $\mathrm{Ni}$ uptake by nitrogen fixers that are stimulated by iron $(\mathrm{Fe})$ deposition. The distribution of $\mathrm{Ni}$ resembles the distribution of cadmium (Cd) and also features a so called kink (change in the steepness of slope) in the $\mathrm{Ni}-\mathrm{PO}_{4}$ relationship. Like for $\mathrm{Cd}$, this is caused by the mixing of Nordic and Antarctic origin water masses. The overall distribution of $\mathrm{Ni}$ is driven by mixing with an influence of regional remineralization. This influence of remineralization is, with a maximum remineralization contribution of $13 \%$ of the highest observed concentration, smaller than for $\mathrm{Cd}(30 \%)$, but larger than for zinc (Zn; 6\%). The uptake pattern in the formation regions of Antarctic origin water masses is suggested to be more similar to $\mathrm{Zn}$ than to $\mathrm{Cd}$, however, the surface concentrations of $\mathrm{Ni}$ are never fully depleted. This results in a North Atlantic concentration distribution of Ni where the trends of increasing and decreasing concentrations between water masses are similar to those observed for $\mathrm{Cd}$, but the actual concentrations as well as the uptake and remineralization patterns are different between these elements.

Keywords: GEOTRACES GA02, dissolved nickel, dissolved cadmium, dissolved zinc, west Atlantic

\section{INTRODUCTION}

Primary productivity in the oceans depends on the availability of light and nutrients, among which are several essential trace elements. All phytoplankton need, in order of average requirement, the trace elements iron $(\mathrm{Fe})$, zinc $(\mathrm{Zn})$, manganese $(\mathrm{Mn})$, copper $(\mathrm{Cu})$, nickel $(\mathrm{Ni})$, and cobalt $(\mathrm{Co})$, but other elements such as cadmium $(\mathrm{Cd})$, molybdenum $(\mathrm{Mo})$, vanadium $(\mathrm{V})$, and selenium $(\mathrm{Se})$ 
are important for specific taxonomic groups [e.g. (Morel et al., 2014; De Baar et al., 2018)]. Of the bio-essential trace metals, nickel remains the least studied. Despite being an essential element in the assimilation of urea as well as in some superoxide dismutase (SOD) enzymes (e.g. Dupont et al., 2008, 2010), the ocean surface concentrations of $\mathrm{Ni}$ remain usually well above $1 \mathrm{nM}$ with the exception of some stations in the Indian Ocean where concentrations as low as $0.6 \mathrm{nM}$ were observed (Thi Dieu Vu and Sohrin, 2013). With the exception of this incomplete drawdown in the surface ocean, the distribution of $\mathrm{Ni}$ in the ocean is that of a nutrient type element. Notably, the concentrations of $\mathrm{Ni}$ are known to correlate with the major nutrients nitrate $\left(\mathrm{NO}_{3}\right)$, phosphate $\left(\mathrm{PO}_{4}\right)$, and silicate (Si) (e.g. Bruland, 1980; Ellwood, 2008; Butler et al., 2013; Thi Dieu $\mathrm{Vu}$ and Sohrin, 2013). As a consequence of the incomplete Ni drawdown, such correlations are characterized by a positive intercept, i.e. there is "left over" $\mathrm{Ni}$ at (near) complete utilization of $\mathrm{NO}_{3}$ or $\mathrm{PO}_{4}$. For example, in the Sub-Antarctic Zone south of Tasmania, a seasonal depletion up to only $20 \%$ of the winter stock was calculated (Butler et al., 2013). The excess of $\mathrm{Ni}$ that exists after drawdown of the other nutrients might be an indication that not all $\mathrm{Ni}$ is bio-available. However, $\mathrm{Ni}$ is not known to be chelated by organic ligands to a degree that would hinder biological uptake (e.g. Van Den Berg and Nimmo, 1987; Nimmo et al., 1989; Saito et al., 2004; Morel et al., 2014), but little is known about the binding strength of organonickel complexes and it is feasible part of the dissolved $\mathrm{Ni}$ pool is irreversibly complexed on timescales relevant for biological uptake. Alternatively, it has been suggested that the relatively high concentrations of $\mathrm{Ni}$ in the surface ocean could be related to an upper limit to the number of membrane proteins for uptake that can be present per cell, combined with the relatively slow kinetics of uptake due to the inertness of the $\mathrm{Ni}^{2+}$ ion (Morel et al., 1991, 2014; Price and Morel, 1991). Additionally, the relatively slow uptake kinetics and relatively poor selectivity for $\mathrm{Ni}$ of divalent metal transporters, might lead to metal toxicity of other metals transported along with $\mathrm{Ni}$ (Egleston and Morel, 2008). Thus despite their need for $\mathrm{Ni}$, marine phytoplankton might be unable to deplete the Ni concentration to very low concentrations (Morel et al., 2014 and references therein). Dupont et al. (2010), demonstrated in bottle incubation experiments using surface seawater from the Gulf of California that $\mathrm{Ni}$ additions could stimulate the growth of cyanobacteria and pico-eukaryotes. This would imply $\mathrm{Ni}$ can be limiting, but remarkably, the growth stimulation was achieved with $\mathrm{Ni}$ additions only one quarter of the ambient $\mathrm{Ni}$ concentrations. This in turn would imply $>97 \%$ of total ambient dissolved $\mathrm{Ni}$ would be complexed by organic ligands that render the Ni nonbioavailable to the local Gulf of California community, which was noted by Dupont et al. (2010) to be at odds with previous reports of Ni speciation in seawater. Assuming no more than $10 \%$ of the cellular outer membrane is available for membrane proteins, small phytoplankton like cyanobacteria probably need a free (i.e. not complexed) $\mathrm{Ni}$ concentration in the order of 100-200 $\mathrm{pmol} \mathrm{L}^{-1}$ whereas larger diatoms need in the order of 750-1500 $\mathrm{pmol} \mathrm{L}^{-1}$, depending on the Fe concentration (Dupont et al., 2010). These concentrations are lower than, or in the range of, total dissolved Ni concentrations in the surface ocean, but as mentioned, which fraction is bio-available is currently unknown. Thus, whether uptake kinetics, cellular membrane space limitations, complexation of $\mathrm{Ni}$, or possibly a combination of these factors is responsible for the incomplete drawdown of $\mathrm{Ni}$ by phytoplankton in the surface remains an outstanding question, but $\mathrm{Ni}$ availability can exert control on marine primary productivity and community composition. This was also corroborated by Ho (2013), who demonstrated the growth of Trichodesmium, a diazotrophic cyanobacteria species, can be limited by inadequate $\mathrm{Ni}$ availability in natural seawater, despite a total dissolved $\mathrm{Ni}$ concentration of $2 \mathrm{nmol} \mathrm{L}{ }^{-1}$. Additionally, diatoms appear to have relatively high $\mathrm{Ni}$ requirements and about half the $\mathrm{Ni}$ is associated with the intracellular organic matter and the other half with the siliceous frustule (Twining et al., 2012). Both diatoms and diazotrophs might thus play a key role in the marine Ni cycling and distribution. However, only limited research has been done and thus it can not be concluded with certainty these specific types of phytoplankton play a key role in the cycling of Ni.

Besides the uptake of Ni by marine organisms, not much is known about the sources and sinks of $\mathrm{Ni}$ in the open ocean and its distribution seems to be mainly determined by internal cycling (Bowie et al., 2002). The effect of atmospheric input appears limited, either via wet or dry deposition, but continental run off and/or shelf processes have been reported to be a source of Ni (Westerlund et al., 1986; Bowie et al., 2002). Cameron and Vance (2014) postulated that fluvial input is the main source of $\mathrm{Ni}$, where notably particulate $\mathrm{Ni}$ that is deposited in estuaries, and subsequently remobilised under anoxic conditions, could be an important process supplying dissolved $\mathrm{Ni}$ to the ocean. It is clear that there still is an incomplete understanding of the biogeochemical cycle of $\mathrm{Ni}$ and the role $\mathrm{Ni}$ plays in marine primary productivity, and that there is a paucity of $\mathrm{Ni}$ data for the open ocean. For the generally well-studied Atlantic Ocean, some data is available for the distribution of $\mathrm{Ni}$, with concentrations of $\sim 2 \mathrm{nmol} \mathrm{L}^{-1}$ in the surface up to $\sim 6 \mathrm{nmol} \mathrm{L}^{-1}$ in the deep [e.g. (Danielsson et al., 1985; Jickells and Burton, 1988; Landing et al., 1995; Saager et al., 1997; Bowie et al., 2002)]. However, these previous studies mostly focused on restricted regions and more recently, the analytical and sampling procedures have been improved due to the global GEOTRACES efforts.

Here we report on the concentrations of $\mathrm{Ni}$ that were measured in 1433 samples collected along the $\sim 17,500 \mathrm{~km}$ long GEOTRACES GA02 section of the Netherlands in a campaign of four consecutive GEOTRACES cruises (2010-2012). This offers the opportunity to assess the distribution of dissolved $\mathrm{Ni}$ along the complete West Atlantic Ocean, following the southward traveling deep North Atlantic Deep Water (NADW) as well as the northward traveling Antarctic origin water masses. The $\mathrm{Ni}$ measurements were all done by the same analysist and members of the specialized NIOZ nutrient laboratory performed the shipboard nutrient measurements, generating a very large, internally consistent, data set. This allows variations to be attributed to oceanic processes instead of analytical variability, akin to our previous studies of Cd (Middag et al., 2018) and Zn (Middag et al., 2019). The aim of the current study is to assess 
the basin wide distribution of $\mathrm{Ni}$ in the entire West Atlantic Ocean and to distinguish between the effects of biogeochemical processes and water mass advection and mixing.

\section{MATERIALS AND METHODS}

\section{Sample Collection and Analysis}

The collection of samples along the GEOTRACES GA02 Atlantic Meridional section of the Netherlands (Figure 1A) has been detailed previously (Middag et al., 2015b, 2018). Very briefly, samples were collected using the NIOZ “Titan” system (De Baar et al., 2008) with "Pristine" samplers (Rijkenberg et al., 2015). Along the section that was sampled during four consecutive expeditions, a total of 60 full depth stations were occupied where 24 depths were sampled. Subsamples were taken inside a clean room environment within a modified high cube shipping container. Subsamples for major nutrients were unfiltered, whereas metal samples were filtered over a $0.2 \mu \mathrm{m}$ filter cartridge (Sartobran-300, Sartorius) under nitrogen gas pressure (0.5 bar overpressure) and collected in acid cleaned LDPE bottles. Subsamples were analyzed as described previously (Middag et al., 2018). For $\mathrm{Ni}$, the limit of detection (three times the standard deviation of the average blank) was $0.07 \mathrm{nmol} \mathrm{kg}^{-1}$. Of the 1433 samples analyzed (for seven of the 1440 samples, extraction failed and samples were not analyzed), nine were flagged as outliers [see (Middag et al., 2011) for criteria] and not used in the dataset. No values were below the limit of detection. As reported previously, results for reference samples (GEOTRACES and SAFe; Table 1) were in agreement with consensus values and results at the BATS crossover station agree well with data obtained by others at the same station (Middag et al., 2015a). The data was submitted to the GEOTRACES standards and Intercalibration committee who acknowledged the data as intercalibrated and this data is part of the GEOTRACES intermediate data products (Mawji et al., 2015; Schlitzer et al., 2018). For the major nutrients [nitrate $\left(\mathrm{NO}_{3}\right)$,
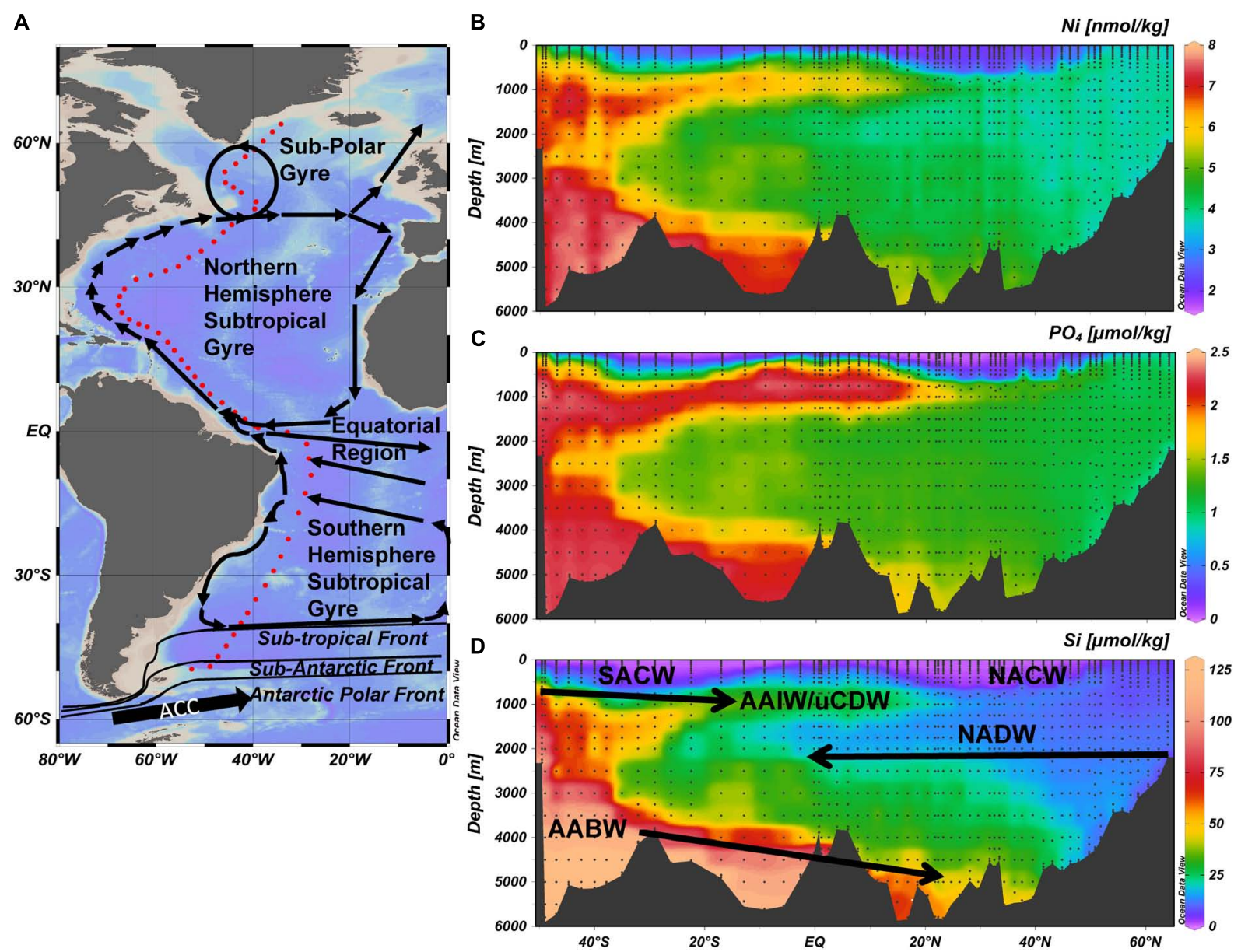

FIGURE 1 | The GEOTRACES GA02 section in the West Atlantic Ocean (A) The 17500 km long GEOTRACES GA02 section in the West Atlantic Ocean based on four cruises and comprising 60 stations (red dots) with 24 sampling depths each; and a general overview of the surface ocean circulation and key oceanographic features. (B) The concentration of dissolved $\mathrm{Ni}$ in color scale along the transect. (C) The concentration of dissolved PO 4 in color scale along the transect. (D) The concentration of dissolved Si in color scale along the transect. Note the color scale is not linear for (D) to better visualize the elevated concentrations of Si in AAIW/uCDW. Abbreviations: AABW, Antarctic Bottom Water; AAIW, Antarctic Intermediate Water; NACW, North Atlantic Central Water; NADW, North Atlantic Deep Water; SACW, South Atlantic Deep Water; uCDW, upper circumpolar deep water. 
TABLE 1 | Concentrations of $\mathrm{Ni}\left(\mathrm{nmol} \mathrm{kg}^{-1}\right.$ ) for reference samples (GEOTRACES and SAFe) as obtained in this study as well as a compilation of previously reported values and the 2013 consensus values as reported on the GEOTRACES website (www.geotraces.org).

\begin{tabular}{|c|c|c|c|c|c|}
\hline & SAFE S1 (n) & SAFE D1 (n) & SAFe D2 (n) & GS (n) & GD (n) \\
\hline This study & $2.25 \pm 0.05(13)$ & & $8.51 \pm 0.1(13)$ & $2.06 \pm 0.06(13)$ & $4.00 \pm 0.08(13)$ \\
\hline Biller and Bruland, 2012 & $2.23 \pm 0.019(3)$ & & $8.51 \pm 0.05(3)$ & $2.00 \pm 0.01$ & $3.90 \pm 0.07(3)$ \\
\hline Bown et al., 2017 & & & $8.69 \pm 0.22(7)$ & & \\
\hline Butler et al., 2013* & $2.41 \pm 0.19(10)$ & & $8.62 \pm 0.50(8)$ & & \\
\hline Cloete et al., 2019 & & & $8.13 \pm 0.1$ & & \\
\hline Ellwood, 2008 & $2.24 \pm 0.25(3)$ & $9.48 \pm 0.03(3)^{\wedge}$ & $9.16 \pm 0.48(3)^{\wedge}$ & & \\
\hline Jackson et al., 2018 & $2.43 \pm 0.05(6)$ & & $9.05 \pm 0.12(9)^{\wedge}$ & & \\
\hline Kondo et al., 2016\# & & & $8.47(1)$ & & $4.07(2)$ \\
\hline Lagerström et al., 2013 & $2.32 \pm 0.08(69)$ & & $8.53 \pm 0.21(48)$ & $2.08 \pm 0.07(58)$ & $3.98 \pm 0.08$ (43) \\
\hline Milne et al., 2010* & $2.40 \pm 0.02(3)$ & & $8.54 \pm 0.21(3)$ & & \\
\hline Minami et al., 2015 & & & & $2.18 \pm 0.08$ & $4.22 \pm 0.10(4)$ \\
\hline Quéroué et al., 2014* & $2.14 \pm 0.1(15)$ & & $7.90 \pm 0.49(15)^{\wedge}$ & $1.95 \pm 0.06(9)$ & \\
\hline Rapp et al., 2017* & $2.36 \pm 0.08(11)$ & $8.48 \pm 0.19(13)$ & $9.39 \pm 0.17(7)^{\wedge}$ & & \\
\hline Sohrin et al., 2008 & $2.25 \pm 0.05$ & & $8.74 \pm 0.15$ & & \\
\hline Takano et al., 2017 & & 8.73 & 8.76 & & \\
\hline Wuttig et al., 2019 & $2.35 \pm 0.16(15)$ & $8.90 \pm 0.42(20)$ & $8.25 \pm 0.12(3)$ & & $4.18 \pm 0.19(6)$ \\
\hline average & $2.31 \pm 0.09$ & $8.90 \pm 0.43$ & $8.62 \pm 0.39$ & $2.05 \pm 0.09$ & $4.05 \pm 0.12$ \\
\hline outliers excluded ${ }^{\wedge}$ & $2.31 \pm 0.09$ & $8.70 \pm 0.21$ & $8.52 \pm 0.19$ & $2.05 \pm 0.09$ & $4.05 \pm 0.12$ \\
\hline 2013 consensus & $2.28 \pm 0.09$ & $8.58 \pm 0.26$ & $8.63 \pm 0.25$ & $2.08 \pm 0.06$ & $4.00 \pm 0.10$ \\
\hline
\end{tabular}

Values are reported as average \pm one standard deviation (if reported) and the number of analyses. The compilation includes all values that, to the best our knowledge,

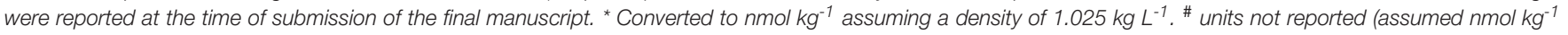
given the reference values reported as well). ${ }^{\wedge}$ Values were excluded if they fell outside the range of the average $\pm 2 S D$ (after exlusion).

nitrite $\left(\mathrm{NO}_{2}\right)$, phosphate $\left(\mathrm{PO}_{4}\right)$, and silicate [ $\mathrm{Si}$ as $\left.\mathrm{Si}(\mathrm{OH})_{4}\right)$ ], the precision of a reference sample was typically around $0.6 \%$ of the average value for $\mathrm{Si}, \mathrm{PO}_{4}, \mathrm{NO}_{3}$ and around $3 \%$ for $\mathrm{NO}_{2}$ (Middag et al., 2018 and references therein). The limits of detection were $0.01,0.03$, and $0.04 \mu \mathrm{mol} \mathrm{kg}{ }^{-1}$ for $\mathrm{PO}_{4}, \mathrm{Si}$ and $\mathrm{NO}_{3}$, respectively.

\section{eOMP Model}

The eOMP model used here was previously described in detail (Middag et al., 2018, 2019, notably the Supplementary Material) and is only briefly described here. Broadly following the methodology outlined by Tomczak (1981, 1999), this model infers the fractional contributions of specific source water types to samples, based on five tracers (potential temperature, salinity, $\mathrm{NO}_{3}, \mathrm{Si}$, and $\mathrm{O}_{2}$ ), also considering the effect of remineralization on the concentrations of $\mathrm{O}_{2}$ and nutrients (see Middag et al., 2018 and references therein). The method infers the deficit of oxygen resulting from remieralization:

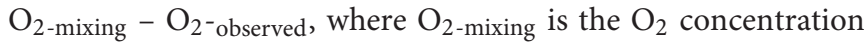
one would expect based on conservative mixing of endmembers. The endmembers are not defined as "pure," or "as-formed" water types, but reflect the observations at the extremes of this ocean section and the model thus only accounts for regional (i.e. within the Atlantic) mixing and remineralization. The purpose of the eOMP is to unravel mixing processes from biogeochemical processes. The robustness and uncertainty of the eOMP solution were assessed using a MonteCarlo simulation approach (one thousand estimates, Middag et al., 2018) where both the characteristics of the endmember water types were varied as well as the remineralization ratios. With water mass fractions and remineralization obtained by the eOMP procedure, estimates are obtained of the optimal $\mathrm{Ni}$ concentrations for each water type as well the $\Delta \mathrm{Ni}: \Delta \mathrm{O}_{2}$ remineralization ratio, via inversion of the system, as done previously for Cd and Zn (Middag et al., 2018, 2019). Note the trace metals were not part of the eOMP itself, rather the eOMP model outcome is used to infer the contribution of water mass mixing to explain the distribution of $\mathrm{Ni}$ as well as the contribution of remineralization and the remineralization ratio (Table 2 ). The uncertainty of the remineralization ratio as well as of the concentrations of $\mathrm{Ni}$ in the endmembers is determined using the same approach as for the general eOMP (Middag et al., 2018).

\section{RESULTS}

\section{Hydrographic Setting}

The hydrography along GEOTRACES GA02 section (Figure 1A) has been described numerous times [e.g. (Rijkenberg et al., 2014; Middag et al., 2015b, 2018)], but will be briefly summarized here as it is directly relevant for the interpretations. North Atlantic Sub-Polar Mode Water (NASPMW) forms the surface water in the most northern part of the transect (Subpolar Gyre). In the North Atlantic Sub-Tropical Gyre (NASTG), North Atlantic Sub-Tropical Mode Water (NASTMW) overlies NASPMW (advected and subducted from the Subpolar Gyre) that in turn overlies North Atlantic Deep Water (NADW). North Atlantic Central Water (NACW) is composed of NASTMW and NASPMW. Formation of NADW mainly takes place in 
TABLE 2 | Predetermined and eOMP endmember solutions (mixing only and optimized mixing and remineralization Model) for the Ni concentration (nmol $\mathrm{kg}^{-1}$ ) in the various water types. Additionally the calculated dissolved $\mathrm{Ni} / \mathrm{PO}_{4}, \mathrm{Cd} / \mathrm{PO}_{4}$, and $\mathrm{Zn} / \mathrm{PO}_{4}$ ratios are reported for the endmember water masses.

\begin{tabular}{|c|c|c|c|c|c|c|c|c|c|}
\hline \multirow[t]{2}{*}{ Water type } & \multirow{2}{*}{$\begin{array}{c}\text { Pre- } \\
\text { determined } \\
{[\mathrm{Ni}]}\end{array}$} & \multirow{2}{*}{$\begin{array}{c}\begin{array}{c}\text { Optimized mixing } \\
\text { only }\end{array} \\
{[\mathrm{Ni}]}\end{array}$} & \multicolumn{7}{|c|}{ Optimized mixing and remineralization with uncertainty estimate } \\
\hline & & & {$[\mathrm{Ni}]$} & $\mathrm{Ni} / \mathrm{PO}_{4}$ & $\begin{array}{c}\mathrm{Ni} / \mathrm{PO}_{4} \\
\text { corrected }^{*}\end{array}$ & {$[\mathrm{Cd}]^{1}$} & $\mathrm{Cd} / \mathrm{PO}_{4}{ }^{1}$ & {$[\mathrm{Zn}]^{2}$} & $\mathrm{Zn} / \mathrm{PO}_{4}{ }^{2}$ \\
\hline AABW & 7.50 & 7.74 & $7.72 \pm 0.02$ & $3.35 \pm 0.02$ & $2.57 \pm 0.01$ & $0.784 \pm 0.002$ & $0.34 \pm 0.01$ & $7.67 \pm 0.02$ & $3.33 \pm 0.02$ \\
\hline UCDW & 7.50 & 7.68 & $7.29 \pm 0.05$ & $3.10 \pm 0.04$ & $2.34 \pm 0.03$ & $0.813 \pm 0.007$ & $0.35 \pm 0.01$ & $4.90 \pm 0.06$ & $2.08 \pm 0.04$ \\
\hline AAIW & 5.50 & 5.81 & $5.59 \pm 0.02$ & $3.13 \pm 0.03$ & $2.12 \pm 0.02$ & $0.528 \pm 0.004$ & $0.30 \pm 0.01$ & $1.18 \pm 0.02$ & $0.66 \pm 0.02$ \\
\hline SASPMW & 4.00 & 4.30 & $3.74 \pm 0.03$ & $5.05 \pm 0.12$ & $2.62 \pm 0.07$ & $0.073 \pm 0.005$ & $0.09 \pm 0.01$ & $0.01 \pm 0.01$ & $0.02 \pm 0.02$ \\
\hline SASTMW & 2.70 & 2.59 & $2.43 \pm 0.02$ & N/A & $\mathrm{N} / \mathrm{A}$ & 0 & $\mathrm{~N} / \mathrm{A}$ & 0.00 & N/A \\
\hline DSOW & 3.60 & 3.55 & $3.60 \pm 0.02$ & $3.89 \pm 0.05$ & $1.95 \pm 0.03$ & $0.190 \pm 0.002$ & $0.21 \pm 0.01$ & $1.08 \pm 0.03$ & $1.16 \pm 0.04$ \\
\hline LSW & 4.20 & 4.08 & $3.94 \pm 0.02$ & $3.73 \pm 0.02$ & $2.02 \pm 0.01$ & $0.238 \pm 0.001$ & $0.22 \pm 0.01$ & $1.34 \pm 0.01$ & $1.27 \pm 0.02$ \\
\hline NASPMW & 3.30 & 3.91 & $3.49 \pm 0.02$ & $5.79 \pm 0.12$ & $2.80 \pm 0.06$ & $0.133 \pm 0.003$ & $0.22 \pm 0.01$ & $0.50 \pm 0.02$ & $0.84 \pm 0.05$ \\
\hline NASTMW & 2.20 & 2.17 & $1.95 \pm 0.02$ & $\mathrm{~N} / \mathrm{A}$ & $\mathrm{N} / \mathrm{A}$ & 0 & $\mathrm{~N} / \mathrm{A}$ & 0.00 & $\mathrm{~N} / \mathrm{A}$ \\
\hline ESW-1 & 2.00 & 1.95 & $1.94 \pm 0.02$ & $\mathrm{~N} / \mathrm{A}$ & $\mathrm{N} / \mathrm{A}$ & 0 & $\mathrm{~N} / \mathrm{A}$ & $0.03 \pm 0.01$ & $\mathrm{~N} / \mathrm{A}$ \\
\hline ESW-2 & 2.20 & 2.13 & $2.10 \pm 0.02$ & $\mathrm{~N} / \mathrm{A}$ & $\mathrm{N} / \mathrm{A}$ & 0 & $\mathrm{~N} / \mathrm{A}$ & $0.06 \pm 0.01$ & $\mathrm{~N} / \mathrm{A}$ \\
\hline $\begin{array}{l}\text { Remin. ratio } \\
\mathrm{M}^{\#}:-\mathrm{O}_{2}\left(\times 10^{-3}\right)\end{array}$ & NA & NA & $0.0046 \pm 0.0002$ & & & $0.00125 \pm 0.002$ & & $0.0024 \pm 0.0001$ & \\
\hline
\end{tabular}

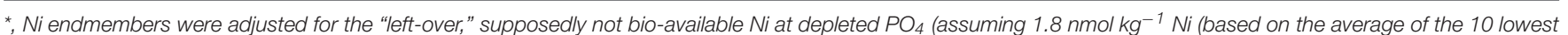

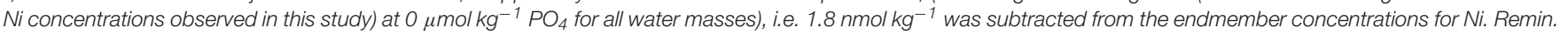

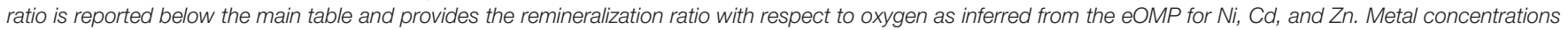
are in $\mathrm{nmol} \mathrm{kg}^{-1} \cdot{ }^{1}$ (Middag et al., 2018); ${ }^{2}$ (Middag et al., 2019), \# M denotes Ni, Cd, and Zn, respectively.

the Labrador Sea and north of the Greenland-Iceland-Scotland Ridge and NADW can be separated in three components; Denmark Strait Overflow Water (DSOW), Labrador Sea Water (LSW) and Iceland-Scotland Overflow Water (ISOW) (ISOW is not distinguished in the OMP). Equatorial Surface Water (ESW) is observed at the lower latitudes and characterized by relatively low salinity. Between $\sim 20^{\circ} \mathrm{N}$ and $\sim 15^{\circ} \mathrm{S}$ an Oxygen Minimum Zone (OMZ) was observed at depths between $\sim 100$ and $1000 \mathrm{~m}$. Along the section, four (sub-)Antarctic water masses can be distinguished, Antarctic Bottom Water (AABW), South Atlantic Sub-Polar Mode Water (SASPMW), Antarctic Intermediate Water (AAIW) and upper Circumpolar Deep water ( $\mathrm{uCDW})$. The AABW is the deepest near bottom water mass formed by deep water formation around Antarctica (also known as Lower Deep Water in the North Atlantic). The SASPMW is also known as Sub Antarctic Mode Water (SAMW), but here the name SASPMW is used to differentiate from varieties present in the Pacific and Indian Oceans. The (sub-)Antarctic water masses all advect northward, AABW along the bottom and the other three at intermediate depth, overlying the southward flowing NADW and underling the South Atlantic Sub-Tropical Mode Water (NASTMW) in the main thermocline of the South Atlantic Sub-Tropical Gyre (SASTG). South Atlantic Central Water (SACW) is composed of SASTMW and SASPMW. Both SASPMW and AAIW are formed from Antarctic surface water where $\mathrm{Si}$ is depleted faster than $\mathrm{NO}_{3}$ and $\mathrm{PO}_{4}$ during northward advection after upwelling of Circumpolar Deep Water. Therefore SASPMW can be recognized by its relatively high concentrations of $\mathrm{NO}_{3}$ and $\mathrm{PO}_{4}$ with respect to $\mathrm{Si}$ (Sarmiento et al., 2004) whereas this excess $\mathrm{NO}_{3}$ and $\mathrm{PO}_{4}$ with respect to $\mathrm{Si}$ is less profound in AAIW as it is formed further south. The Antarctic origin intermediate depth water masses (SASPMW, AAIW, uCDW) and AABW are similarly elevated in $\mathrm{NO}_{3}$ and $\mathrm{PO}_{4}$ with respect to the NADW, whereas $\mathrm{Si}$ is mainly elevated in $\mathrm{AABW}$ due to the deeper remineralization of $\mathrm{Si}$.

\section{Distribution of Dissolved Ni}

The general distribution of $\mathrm{Ni}$ (Figure 1B) is consistent with previous observations in the North Atlantic Ocean. For example, for NADW, concentrations of $\mathrm{Ni}$ in the range of $3-4 \mathrm{nmol} \mathrm{kg}-1$ have been reported (Danielsson et al., 1985; Saager et al., 1997; Bowie et al., 2002) despite differences in sampling and the absence of a filtration step for some of the earlier studies. This implies $\mathrm{Ni}$ is not as contamination sensitive as other metals such as $\mathrm{Fe}$ or $\mathrm{Zn}$, and that most $\mathrm{Ni}$ is present in the dissolved $(<0.2 \mu \mathrm{m})$ fraction, or that $\mathrm{Ni}$ in particles is not leachable by acidification of an unfiltered sample.

The distribution of dissolved $\mathrm{Ni}$ resembles the distribution pattern of $\mathrm{Cd}$ as well as the similar distribution patterns of $\mathrm{NO}_{3}$ and $\mathrm{PO}_{4}$ (Figure 1C) better than it resembles the distribution pattern of Si (Figure 1D) and Zn. However, the concentrations of $\mathrm{Ni}$ while low, are not depleted to near zero concentrations in the surface ocean, with a lowest observed concentration of $1.7 \mathrm{nmol} \mathrm{kg} \mathrm{kg}^{-1}$ (Figure 1B). As previously observed for Cd and Zn (Middag et al., 2018), surface concentrations are elevated toward the northern and southern end of the transect, with values for $\mathrm{Ni}$ up to $4.9 \mathrm{nmol} \mathrm{kg}^{-1}$ in the

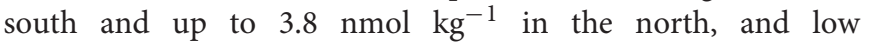
surface concentrations persist to greater depths in the northern and southern subtropical gyres than at higher and lower latitudes. The shoaling of $\mathrm{Ni}$ isolines is probably the result of upwelling in the equatorial regions, as well as the inflows of 
relatively high $\mathrm{Ni}$ waters on the northern and southern ends of the transect.

\section{DISCUSSION}

\section{Surface Distribution}

The relatively low concentrations of $\mathrm{Ni}$ in surface waters (Figure 2) imply that any input from external sources such as atmospheric deposition is very small, or that any input is matched by loss factors of equal magnitude. Interestingly, however, surface concentrations of $\mathrm{Ni}$ were lower in the Northern Hemisphere (NH) compared to the Southern Hemisphere (SH), whereas dust deposition is known to be higher in the NH (Gao et al., 2001). Specifically, the average Ni concentration in the upper $100 \mathrm{~m}$ between the equator and $40^{\circ} \mathrm{N}$ was with $2.06 \mathrm{nmol} \mathrm{kg}-1$ (standard deviation $0.15 \mathrm{nmol} \mathrm{kg}{ }^{-1}$ ) significantly lower (onetailed $t$-test; $p<0.001$ ) than the average $\mathrm{Ni}$ concentration in the upper $100 \mathrm{~m}$ between the equator and $40^{\circ} \mathrm{S}$ with $2.52 \mathrm{nmol}$ $\mathrm{kg}^{-1}$ (standard deviation $0.28 \mathrm{nmol} \mathrm{kg}^{-1}$ ) (and a similar result for the upper $50 \mathrm{~m}$ ). Previously, it was noted that surface concentrations of aluminum (Al) (Middag et al., 2015b), Fe (Rijkenberg et al., 2014), and Mn (Van Hulten et al., 2017) were most elevated between $20-30^{\circ} \mathrm{N}$, which was attributed to atmospheric deposition, whereas $\mathrm{Cd}$ and $\mathrm{Zn}$ did not show an obvious increase (Middag et al., 2018, 2019). The concentrations of $\mathrm{Ni}$ are $\sim 2 \mathrm{nmol} \mathrm{kg}^{-1}$ in this region and the lowest surface concentrations are observed between $10-20^{\circ} \mathrm{N}$. In this region, the influence of the Amazon River is noticeable in lower salinities at some stations (Rijkenberg et al., 2014), but no coinciding increase is observed for $\mathrm{Ni}$. In this region (between $10-20^{\circ} \mathrm{N}$ ), the $\mathrm{Al}$, $\mathrm{Fe}$, and $\mathrm{Mn}$ concentrations were elevated due to dust deposition (and possibly some local fluvial influence), but not to the same extend as between $20-30^{\circ} \mathrm{N}$. This implies dust deposition and fluvial input contributes little or negligible to the distribution of $\mathrm{Ni}$ in the sampling region, or alternatively, any input is rapidly depleted by biological uptake. With regards to the latter hypothesis, please be aware that even the lowest concentrations of $\mathrm{Ni}$ observed are still around $2 \mathrm{nmol} \mathrm{\textrm {kg } ^ { - 1 }}$. This would imply the "ambient" dissolved $\mathrm{Ni}$ is not bioavailable whereas any additional $\mathrm{Ni}$ input would have to be readily available and taken up. As detailed in the introduction, rapid Ni uptake after addition despite relatively high ambient $\mathrm{Ni}$ concentrations (>3 nmol kg-1) has been observed before (Dupont et al., 2010), indicating that indeed the ambient Ni pool might not be bio-available whereas newly added $\mathrm{Ni}$ can be bio-available. It should be noted, however, this was observed in experiments using water from a different region with different biological, chemical and oceanographic conditions and thus those results are not necessarily representative for processes in the current study region. Whether or not atmospheric dust is an important source of $\mathrm{Ni}$ to the study region can not be determined from our current study, but aerosol measurements near Bermuda show $\mathrm{Ni}$ is a minor component of aerosols compared to $\mathrm{Al}$ and $\mathrm{Fe}$ (Fishwick et al., 2014). Nevertheless, addition of Saharan dust in Mediterranean mesocosm experiments (addition of $1 \mathrm{mg}$ dust per liter seawater) led to an increase in $\mathrm{Ni}$ of about $2 \mathrm{nM}$ (Herut et al., 2016), indicating dust can be source of $\mathrm{Ni}$ to the ocean. To assess if dust contributes to the overall $\mathrm{Ni}$ inventory (dissolved and particulate) in the study region, future work should also assess the particulate Ni concentration in conjunction with the dissolved concentrations. Additionally, to further constrain the importance of $\mathrm{Ni}$, it should be determined if the low dissolved $\mathrm{Ni}$ concentrations in the region of known dust input coincide with elevated $\mathrm{Ni}$ in the biogenic fraction and whether or not phytoplankton growth in this region can be stimulated by $\mathrm{Ni}$ additions.

It is conceivable that the lower surface concentrations of $\mathrm{Ni}$ in the NASTG compared to the SASTG are related to nitrogen fixation as nitrogen fixing microbes such as Trichodesmium are thought to have a relatively high $\mathrm{Ni}$ requirement (Nuester et al., 2012; Ho, 2013; Ho et al., 2013; Rodriguez and Ho, 2014) and

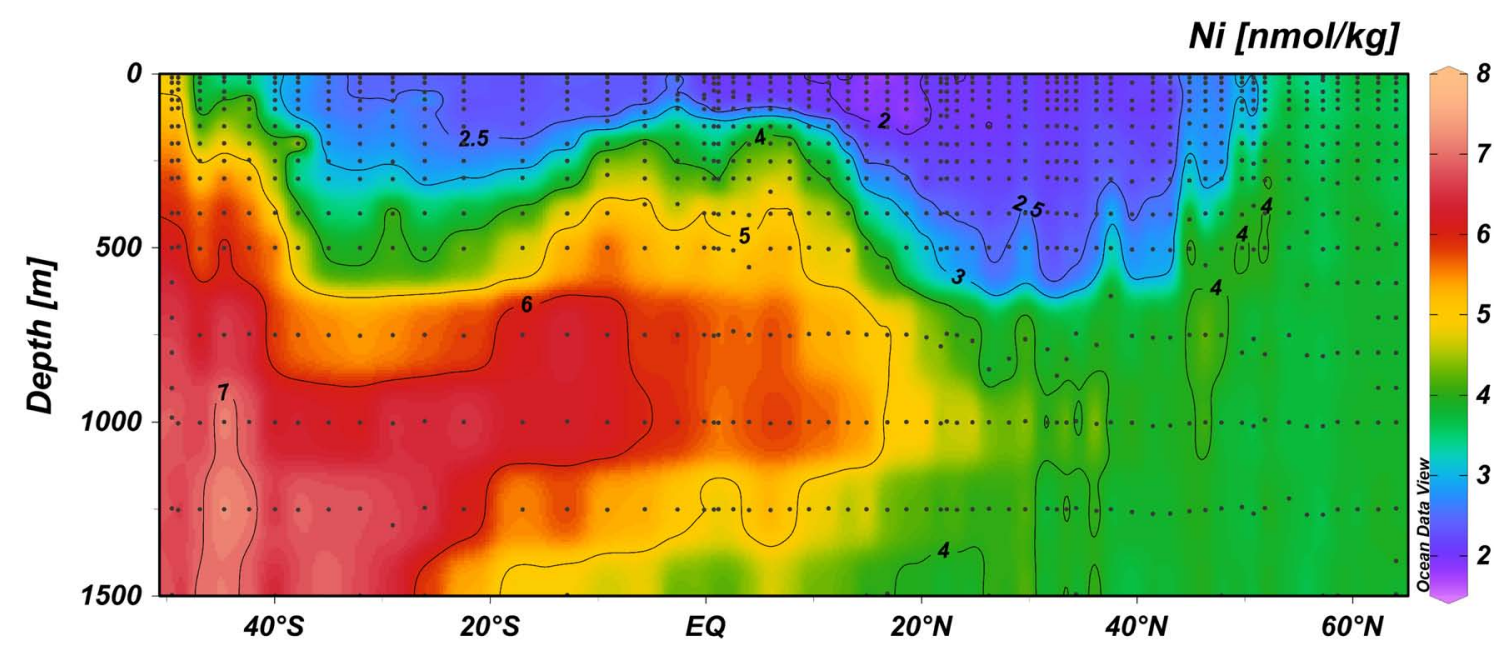

FIGURE 2 | The distribution of the concentration of $\mathrm{Ni}(\mathrm{nmol} / \mathrm{kg})$ at expanded depth scale in the upper $1500 \mathrm{~m}$ depth range, along the GA02 section in non-linear color scale to best visualize the concentration gradients (auto adjust function of ODV). 
estimates of nitrogen fixation are higher for the NA compared to the SA (Benavides and Voss, 2015). Our data in the WestAtlantic is consistent with this notion and the hypothesis of Schlosser et al. (2014) who postulated that wet dust deposition in the Intertropical Convergence Zone (ITCZ) delivers Fe to the subtropical NA and this Fe stimulates nitrogen fixation. As the observed concentrations of a nutrient element such as Fe are the resultant of the balance between supply and uptake, the observed concentrations are not necessarily representative of supply. Even though the concentrations of dissolved $\mathrm{Al}$, a non-nutrient dust tracer, are affected by scavenging onto biogenic particles (Middag et al., 2015b), concentrations of $\mathrm{Al}$ are correlated to the concentrations of $\mathrm{Ni}$ in the upper $100 \mathrm{~m}$ in the subtropical gyres (Figure 3A) along the GA02 section. However, the relationship is non-linear as with concentrations of $\mathrm{Al}>\sim 35 \mathrm{nmol} \mathrm{kg}^{-1}$, the concentrations of $\mathrm{Ni}$ do no longer decrease and sit around the minimum observed concentrations of $\sim 2 \mathrm{nmol} \mathrm{kg}^{-1}$. Outside the gyres, lower $\mathrm{Al}$ concentrations $\left(<\sim 8 \mathrm{nmol} \mathrm{\textrm {kg } ^ { - 1 }}\right)$ are observed that coincide with steeply increasing Ni concentrations. A similarly shaped trend between $\mathrm{Ni}$ and $\mathrm{Fe}$, where the lowest $\mathrm{Ni}$ concentrations broadly correspond to the region where the highest surface iron concentrations are observed (Figure 3B; similar for $\mathrm{Ni}$ and $\mathrm{Mn}$, not shown), implies that there indeed might be a coupling between Fe deposition, nitrogen fixation and $\mathrm{Ni}$ uptake that warrants further investigation. As noted previously, uptake of $\mathrm{Ni}$ seems to cease around a concentration of $\sim 2 \mathrm{nmol} \mathrm{kg}{ }^{-1}$, with the lowest concentrations of $\mathrm{Ni}$ in regions with the highest estimates for nitrogen fixation. This implies either nitrogen fixers are able to deal with low $\mathrm{Ni}$ availability, perhaps by using non Ni-based enzymes for nitrogen fixation, or they might be limited by low Ni availability. Ho (2013) initially suggested the primary role of nitrogen $\mathrm{Ni}$ in nitrogen fixation by Trichodesmium is in Ni-based SOD that protects the nitrogenase enzyme (nitrogen fixation enzyme) from superoxide inhibition during photosynthesis. Given the elevated concentrations of Mn in the subtropical gyres (notably the NASTG) (Van Hulten et al., 2017), a Mn based SOD would be a likely candidate to replace Ni-SOD in Trichodesmium as the genome contains the gene coding for Mn-SOD as well (Dupont et al., 2008). Based on the current observations of lowest $\mathrm{Ni}$ concentrations in regions of known elevated nitrogen fixation, but most notably given observations elsewhere that nitrogen fixation can be stimulated by $\mathrm{Ni}$ additions (Ho, 2013; Ho et al., 2013; Rodriguez and Ho, 2014), it would appear Ni-SOD is the preferred SOD for nitrogen fixers in the Atlantic. However, other phototrophic organisms that are abundant in the Atlantic subtropical gyres such as the cyanobacteria Prochlorococcus and Synechococcous (Flombaum et al., 2013) also use Ni-SOD (Priya et al., 2007) and thus the role of $\mathrm{Ni}-\mathrm{SOD}$ in explaining the $\mathrm{Ni}$ depletion pattern in the Atlantic remains speculative. Moreover, Trichodesmium is not the only nitrogen fixer in the Atlantic Ocean (e.g. Langlois et al., 2005) and besides Ni-based SOD, there is another biochemical function for $\mathrm{Ni}$ in diazotrophs. Diazotrophs are known to use a NiFe-hydrogenase (Tamagnini et al., 2002) that would thus require $\mathrm{Ni}$, providing an additional explanation for the higher apparent Ni utilization in regions of enhanced nitrogen fixation. This hydrogenase enzyme can oxidize hydrogen $\left(\mathrm{H}_{2}\right)$ that is a by-product of nitrogen fixation. The produced $\mathrm{H}_{2}$ can inhibit

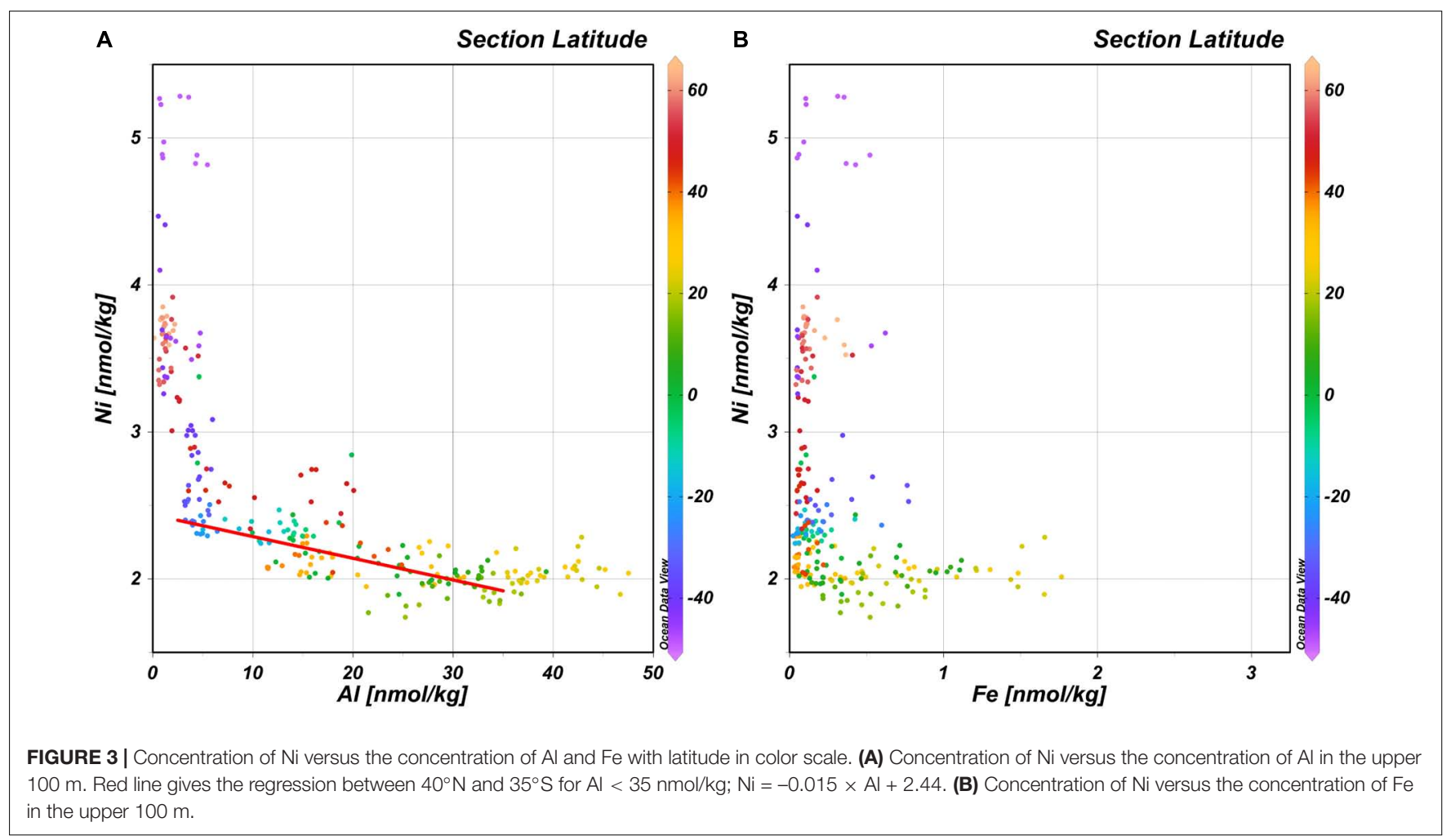


the nitrogen fixation process, thus providing a negative feedback. However, the hydrogenase enzyme protects the nitrogen fixation process and produces energy as well, which in turn can be used for nitrogen fixation (Tamagnini et al., 2002; Nuester et al., 2012; Rodriguez and Ho, 2014). Whether Ni-SOD, NiFe-hydrogenase or the combination of these drive an increase in Ni uptake in the surface ocean, notably the $\mathrm{NH}$, is beyond the scope of this study but would be an interesting subject for further study. Alternatively, despite the elevated Ni requirement of diazotrophs, it is also possible that the strongest depletion of $\mathrm{Ni}$ in the NASTG compared to the SASTG is related to a greater $\mathrm{Ni}$ requirement of the overall $\mathrm{NH}$ microbial community for the $\mathrm{Ni}$ containing urease enzyme or Ni-SOD, but there are no obvious reasons why this should be the case. Overall, it is here suggested the prevalence of diazotrophs in the $\mathrm{NH}$ (due to higher Fe deposition) compared to the $\mathrm{SH}$ could play a role in explaining the observed surface distribution of $\mathrm{Ni}$ in the west Atlantic ocean, but this remains speculative and should be further investigated in experimental studies.

\section{Deep Distribution and Relationship With Nutrients}

For dissolved Al, a strong influence was observed from sediment resuspension in the northern part of the transect (Middag et al., 2015b), but for Ni this does not appear to exert an influence on the near bottom concentrations. If at all, the $\mathrm{Ni}$ concentrations apparently decrease a little toward the sediments in the region north of $40^{\circ} \mathrm{N}$ (Figure 1B), but not as profound as previously observed for Cd and Zn (Middag et al., 2018). This decrease is most likely related to the presence of DSOW that is slightly lower in nutrients and several trace metals than the overlying ISOW and LSW. Generally, the deep distribution of Ni reflects the major nutrients and thus, as previously demonstrated for $\mathrm{Cd}$ and $\mathrm{Zn}$ (Middag et al., 2018, 2019), is governed for an important part by mixing and circulation.

In general, the deep distribution of $\mathrm{Ni}$ is correlated most strongly with $\mathrm{PO}_{4}(r=0.95)$ (and thus $\mathrm{Cd} ; r=0.97$ ) (Figures 4A,B) and less with $\mathrm{Si}(r=0.83)$ and $\mathrm{Zn}$ $(r=0.87)$ (Figures 4C,D) and as reported before by Bruland (1980), the best correlation coefficient is found for the multiple regression of $\mathrm{Ni}$ with both $\mathrm{PO}_{4}$ and $\mathrm{Si}(r=0.98$ for the multiple regression). Previously, it was postulated based on observations in the northeast Atlantic that the biogeochemical cycles of $\mathrm{Ni}$ and Si are not related (Saager et al., 1997). The current larger, high-resolution dataset implies there is a relationship after all, however, whether or not such relationship is discernible, depends on the region and scale of observations. The trends in the distribution of Ni strongly resemble those previously described for the distribution of $\mathrm{Cd}$, implying previous conclusions about the distribution of Cd (Middag et al., 2018) are also broadly applicable to $\mathrm{Ni}$. However, there are some interesting differences as well because $\mathrm{Ni}$ and $\mathrm{Cd}$ are not perfectly correlated (Figure 4B). This is confirmed by using the same eOMP model as described previously (Middag et al., 2018, 2019). In this eOMP approach, fractional contributions of various source water types to samples are inferred. Subsequently the concentrations of $\mathrm{Ni}$ are predicted by multiplication of the assigned $\mathrm{Ni}$ endmember concentrations (estimated from our observations) with these fractions. The predicted $\mathrm{Ni}$ concentrations reflect the measured $\mathrm{Ni}$ concentrations well, where about $95 \%$ of the variation in the observed $\mathrm{Ni}$ is explained by this model (Figure 5A; $R^{2}=0.95$, root mean square error rmse $=0.28 \mathrm{nmol} / \mathrm{kg})$. Obtaining an optimized set of $\mathrm{Ni}$ endmembers (inferred using the eOMP model outcome) slightly improves the fit (Figure 5B; $R^{2}=0.97, \mathrm{rmse}=0.25 \mathrm{nmol} / \mathrm{kg}$ ). Accounting for the effect of remineralization (inferred from the eOMP model outcome) further improves the fit (Figure 5C; $R^{2}=0.98$, rmse $=0.21 \mathrm{nmol} / \mathrm{kg}$ ) with a derived $\mathrm{Ni}: \mathrm{PO}_{4}$ ratio of $0.75 \mathrm{nmol} / \mu \mathrm{mol}$. For $\mathrm{Cd}$, a greater improvement was observed when accounting for the effect of remineralization (40\% reduction in rmse for Cd versus a $13 \%$ reduction for $\mathrm{Ni}$ ), implying a larger influence of remineralization on the $\mathrm{Cd}$ distribution compared to the Ni distribution. Using the eOMPderived remineralization ratios, the maximum observed deficit of oxygen of $\sim 200 \mu \mathrm{mol} \mathrm{kg}-1$ corresponds to a local, Atlantic remineralization signal of $\sim 1.2 \mu \mathrm{mol} \mathrm{kg}{ }^{-1}$ for $\mathrm{PO}_{4}, 0.25 \mathrm{nmol}$ $\mathrm{kg}^{-1}$ for Cd, $0.5 \mathrm{nmol} \mathrm{kg}^{-1}$ for Zn (Middag et al., 2018, 2019) and $0.9 \mathrm{nmol} \mathrm{kg} \mathrm{ng}^{-1}$ for $\mathrm{Ni}$, which corresponds to $~ 50 \%, 30 \%$, $13 \%$, and $6 \%$ of the maximum observed concentrations for $\mathrm{PO}_{4}$, $\mathrm{Cd}, \mathrm{Ni}$, and $\mathrm{Zn}$, respectively. Thus given the concentration ranges in context of remineralization in the study region, the larger effect of remineralization relative to mixing on the distribution of $\mathrm{Cd}$ compared to $\mathrm{Ni}$ in the Atlantic is not surprising. What is remarkable though, is the higher remineralization signal of $\mathrm{Ni}$ compared to $\mathrm{Zn}$, as generally it is assumed that phytoplankton have a larger requirement for $\mathrm{Zn}$ than for $\mathrm{Ni}$ (Twining and Baines, 2013). This suggests the Ni requirement of the overall Atlantic phytoplankton community is relatively high, possibly related to the prevalence of diazotrophs (with a high $\mathrm{Ni}$ requirement) in the Atlantic at lower latitudes (Nuester et al., 2012), this in combination with the low concentration of $\mathrm{Zn}$ in the surface Atlantic Ocean (Middag et al., 2019).

As mentioned previously, the distributions of $\mathrm{Ni}$ and $\mathrm{Cd}$ are overall very similar and both feature a so called "kink," a change in the steepness of the slope, in the relationship with $\mathrm{PO}_{4}$. In the following text, the $\mathrm{Ni}-\mathrm{PO}_{4}$ relationship is systematically assessed from the northern end of the transect toward the equator and from the southern end of the transect toward the equator to identify factors that influence the relationship. This progression southward and northward is based on changes in the relationship that are not obvious when assessing the dataset as a whole. The notation $\mathrm{Ni} / \mathrm{PO}_{4}$ (also for other metals) will be used to indicate a spot ratio (i.e. the dissolved ratio), $\mathrm{Ni}: \mathrm{PO}_{4}$ (also for other metals) to denote either a ratio of particles, and/or an uptake (biological assimilation) or remineralization ratio derived from a regression slope.

When looking at the data from the $\mathrm{NH}$ north of $20^{\circ} \mathrm{N}$, the $\mathrm{Ni}-\mathrm{PO}_{4}$ relationship is best described by multiple regressions that largely correspond to the various water masses and mixing thereof (Figure 6A), where steeper slopes are observed to the right of the kink $\left(\mathrm{PO}_{4} \sim 1.3 \mu \mathrm{mol} \mathrm{kg}{ }^{-1}\right)$. In the Subpolar Gyre, NASPMW is the surface water mass whereas in the NASTG, NASPMW is overlain by NASTMW that has lower $\mathrm{Ni}$ and 


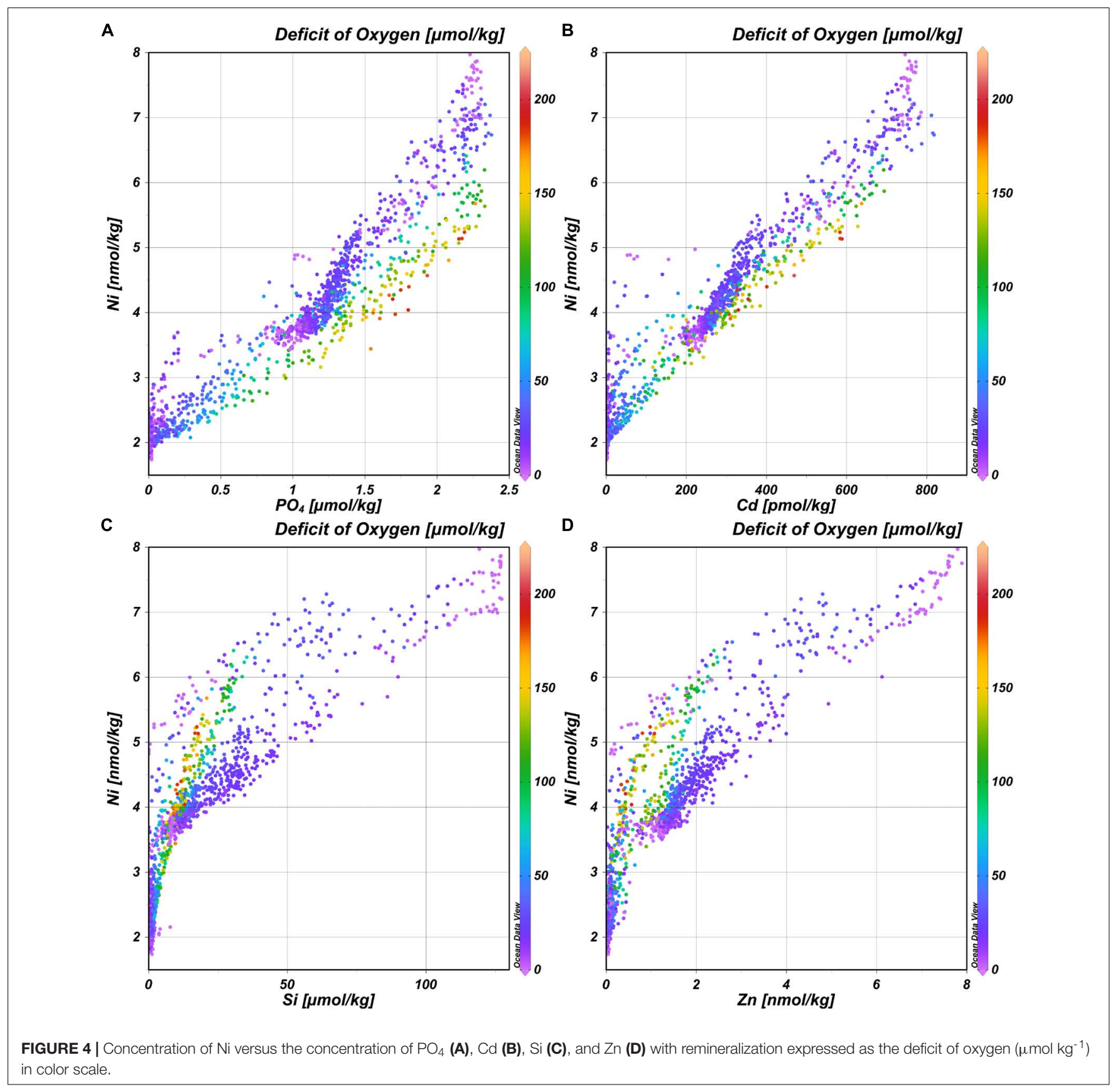

$\mathrm{PO}_{4}$ concentrations. This leads to some scatter as mixing of NASPMW with underlying LSW in the Subpolar Gyre leads to a mixing line that plots above the mixing of NASTMWNASPMW-NADW in the NASTG and both these lines have a slope [0.6 and $1.2 \mathrm{nmol} \mu \mathrm{mol}^{-1}$, green and black regression line, respectively (Table 3)] that is less steep than observed for LSW-DSOW [slope $1.4 \mathrm{nmol} \mu \mathrm{mol}^{-1}$; red regression line (Table 3)]. The higher concentrations correspond to influence of water masses from southern origin (AABW and AAIW) that were influenced by remineralization as evident from the elevated deficit of oxygen. The concentrations are highest in AABW water influenced samples and mixing between NADW and AABW leads to a steeper slope $\left[2.6 \mathrm{nmol} \mu \mathrm{mol}^{-1}\right.$; blue regression line (Table 3)] than mixing between NADW/NACW and AAIW [2.3 $\mathrm{nmol} \mu \mathrm{mol}^{-1}$; pink regression line (Table 3)]. When going south of $20^{\circ} \mathrm{N}$ into the $\mathrm{NH}$ equatorial region (Figure 6B), the influence of the Antarctic origin water masses becomes more apparent, as does the influence of remineralization (based on the deficit of oxygen). The kink in the relationship for the deep water masses can be reproduced using the mixing-only eOMP model, demonstrating the mixing of the northern and southern origin water masses causes this feature (Figure 6C).

Focusing on the SH, starting on the southern end of the transect south of $40^{\circ} \mathrm{S}$ (Figure 6D), the slope of the relationship 

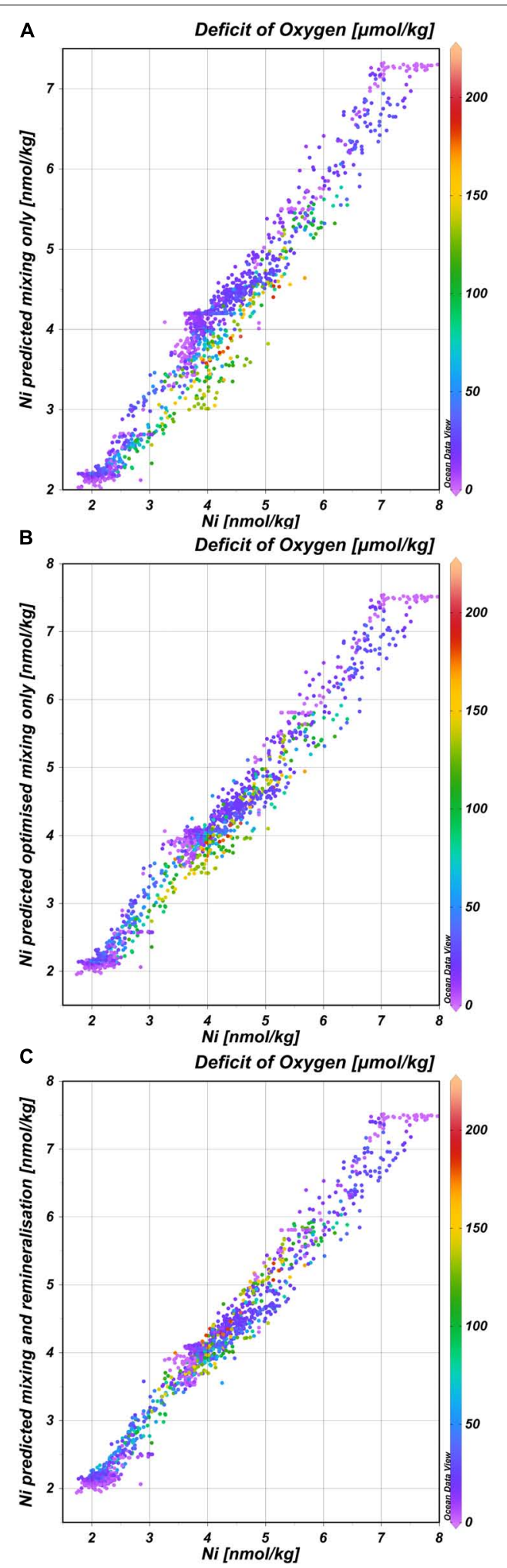

FIGURE 5 | Concentrations of $\mathrm{Ni}$ as predicted by the eOMP model versus the observations. (A) Concentrations of Ni predicted using the estimated endmembers and mixing only ( $\mathrm{Ni}_{\text {pred }}$ ), versus observed $\mathrm{Ni}$ concentrations $\left(\mathrm{Ni}_{\text {obs }}\right) ; \mathrm{Ni}_{\text {pred }}=0.93 \mathrm{Ni}_{\text {obs }}+0.22 ; R^{2}=0.95 ; \mathrm{rmse}=0.28 \mathrm{nmol} \mathrm{kg}^{-1}$.

(Continued)
FIGURE 5 | Continued

(B) Concentrations of Ni predicted using the optimized endmembers and mixing only model, versus observed $\mathrm{Ni}$ concentrations; $\mathrm{Ni}_{\text {pred }}=0.97$ $\mathrm{Ni}_{\text {obs }}+0.13 ; R^{2}=0.97 ;$ rmse $=0.25 \mathrm{nmol} \mathrm{kg}^{-1}$. (C) Concentrations of $\mathrm{Ni}$ predicted using the optimized endmembers for mixing in combination with remineralization based on the deficit of oxygen, versus observed $\mathrm{Ni}$ concentrations; $\mathrm{Ni}_{\text {pred }}=0.98 \mathrm{Ni}_{\text {obs }}+0.10 ; R^{2}=0.98 ; \mathrm{rmse}=0.21 \mathrm{nmol}$ $\mathrm{kg}-1$.

in SASPMW is relatively gentle $\left[1.2 \mathrm{nmol} \mu \mathrm{mol}^{-1}\right.$; yellow regression line (Table 3)] compared to the relationship in underlying water masses AAIW, $\mathrm{uCDW}$ and AABW [2.7 nmol $\mu \mathrm{mol}^{-1}$; purple regression line (Table 3)]. Including all data south of $20^{\circ} \mathrm{S}$ (Figure 6E), it becomes apparent mixing of SASTM-SASPMW-AAIW in the SASTG [slope of $1.4 \mathrm{nmol}$ $\mu \mathrm{mol}^{-1}$; gray regression line (Table 3)] leads to a regression line that plots below the relationship in SASPMW in the far south (south of $40^{\circ} \mathrm{S}$; yellow regression line), similar to observations for the northern equivalent (near) surface water masses. When looking at the entire SH (Figure 6F), the influence of remineralization leads to data with relatively low $\mathrm{Ni}$ concentrations with respect to $\mathrm{PO}_{4}$, i.e. data that plots below the lines of regression determined further south. This is expected given the inferred remineralization ratio of $\mathrm{Ni}: \mathrm{PO}_{4}$ ratio of $0.75 \mathrm{nmol} / \mu \mathrm{mol}$ that is smaller than the slopes of regression, implying the $\mathrm{Ni}: \mathrm{PO}_{4}$ remineralization ratio for the Atlantic is smaller than in the high latitude source regions as previously postulated for the $\mathrm{Cd}: \mathrm{PO}_{4}$ and $\mathrm{Zn}: \mathrm{PO}_{4}$ remineralization ratio as well (Middag et al., 2018, 2019).

The northern origin (NADW) and Antarctic origin (AAIW, $\mathrm{uCDW}$, and $\mathrm{AABW}$ ) deep water masses have different slopes for the Ni-PO 4 relationship (1.43 and $2.62 \mathrm{nmol} \mu \mathrm{mol}^{-1}$, respectively), implying different uptake and remineralization ratios in the various source regions, as previously suggested for $\mathrm{Zn}$ and $\mathrm{Cd}$. There is little data available for dissolved $\mathrm{Ni}$ in the high latitude oceans, but reported observations do suggest higher surface concentrations in the Southern Ocean $\left[\sim 5 \mathrm{nmol} \mathrm{kg}^{-1}\right.$ or higher (Lai et al., 2008; Butler et al., 2013; Cloete et al., 2019; Wang et al., 2019)] than in the open Arctic Ocean outside the Transpolar Drift $\left[\sim 4 \mathrm{nmol} \mathrm{kg}{ }^{-1}\right.$; (Danielsson and Westerlund, 1983; Cid et al., 2012; Gerringa et al., unpublished)] or at the northern end of the current transect (Figure 2). The higher concentrations in the Southern Ocean are most likely due to upwelling of older deep water in this region whereas in contrast, the Arctic is largely supplied by nutrient poor surface water transported north with the Gulf stream [and only a modest amount of old (Pacific) water] (Van Aken, 2007). The steeper slopes in Antarctic origin water masses, suggest relatively higher $\mathrm{Ni}$ uptake in the Southern Ocean as previously suggested for $\mathrm{Cd}$ and Zn (Sunda and Huntsman, 2000; Cullen, 2006). However, reported slopes of regression for the $\mathrm{Ni}-\mathrm{PO}_{4}$ relationship in the Southern Ocean are in the range of $\sim 1.1-1.8 \mathrm{nmol}^{\mu \mathrm{mol}^{-1}}$ (Ellwood, 2008; Butler et al., 2013; Cloete et al., 2019), only slightly steeper or even lower than observed in NADW and less steep than in Antarctic origin water masses along the southern end of this section. Additionally, the $\mathrm{Ni} / \mathrm{PO}_{4}$ endmember ratios (Table 2) are slightly lower in southern than in northern origin 


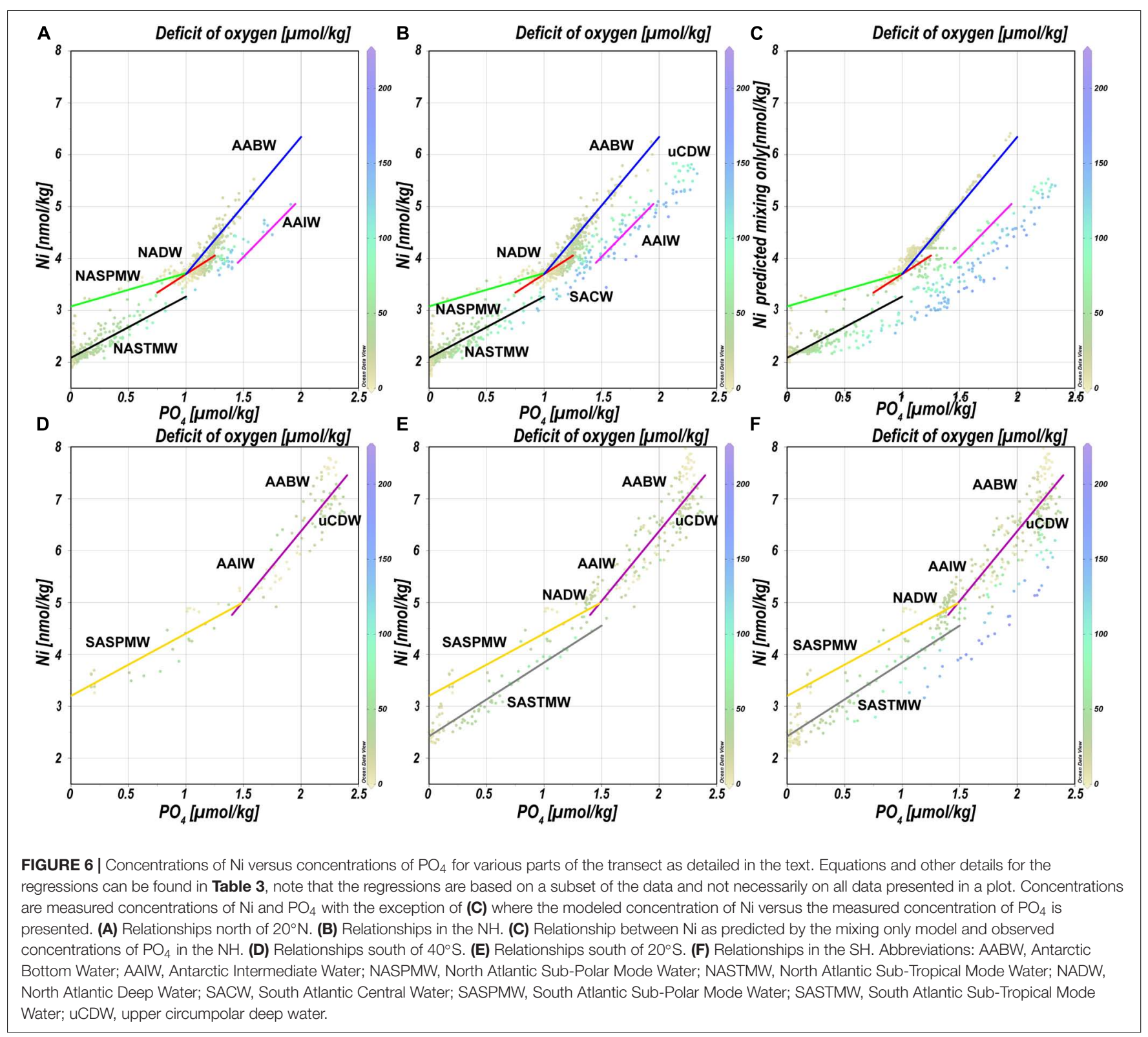

TABLE 3 | Regression lines as depicted in Figure 6

$\mathrm{Ni}-\mathrm{PO}_{4}$ relationship

\begin{tabular}{|c|c|c|c|c|}
\hline \multirow[b]{2}{*}{ Regression } & \\
\hline & equation & $\mathbf{R}^{2}$ & Data selection & $\mathbf{n}$ \\
\hline Subpolar Gyre (sub)surface (green) & $\mathrm{Ni}=0.6 \times \mathrm{PO}_{4}+3.1$ & 0.80 & $>20^{\circ} \mathrm{N} ; \mathrm{NASPMW}>0.75 ; \mathrm{PO}_{4}<1$ & 19 \\
\hline NADW - AABW mixing (blue) & $\mathrm{Ni}=2.6 \times \mathrm{PO}_{4}+1.1$ & 0.79 & $>20^{\circ} \mathrm{N} ; \mathrm{AABW}>0.05$ & 115 \\
\hline NADW/NACW - AAIW mixing (pink) & $\mathrm{Ni}=2.3 \times \mathrm{PO}_{4}+0.6$ & 0.95 & $>20^{\circ} \mathrm{N} ;$ AAIW $>0.05$ & 6 \\
\hline SASTMW - AAIW mixing (yellow) & $\mathrm{Ni}=1.2 \times \mathrm{PO}_{4}+3.2$ & 0.78 & $>40^{\circ} \mathrm{S} ; \mathrm{SASPMW}>0.3$ & 28 \\
\hline SASTG (sub)surface (gray) & $\mathrm{Ni}=1.4 \times \mathrm{PO}_{4}+2.4$ & 0.89 & $<40^{\circ} \mathrm{S}>20^{\circ} \mathrm{S} ; \mathrm{SACW}>0.5$ & 65 \\
\hline
\end{tabular}

Concentrations of $\mathrm{Ni}$ in $\mathrm{nmol} \mathrm{kg}^{-1}$ and concentrations of $\mathrm{PO}_{4}$ in $\mu \mathrm{mol} \mathrm{kg}{ }^{-1}$. All correlations are significant $(\mathrm{p}<0.05)$. Refer to text for details on the various regression lines that are either for specific water masses, or mixing between water masses or components. Data selection refers to the data used for a regression line; e.g. $>50^{\circ} \mathrm{N}$; $N A C W<0.4$ implies all data north of $50^{\circ} \mathrm{N}$ with a fraction NACW as inferred by the eOMP of less than $40 \%$. 
water masses, implying that relative to $\mathrm{PO}_{4}$, there is less $\mathrm{Ni}$ available in southern origin waters. However, given that the $\mathrm{Ni}$ $\mathrm{PO}_{4}$ relationship has a positive intercept, this is an inherent consequence of the higher $\mathrm{PO}_{4}$ endmember concentrations in the south compared to the north (i.e. the higher the $\mathrm{PO}_{4}$ concentrations, the lower the ratio). When correcting the $\mathrm{Ni}$ concentration for the "left-over," supposedly not bio-available $\mathrm{Ni}$ at depleted $\mathrm{PO}_{4}$ (assuming $1.8 \mathrm{nmol} \mathrm{Ni}$ at $\sim 0 \mu \mathrm{mol} \mathrm{kg}{ }^{-1}$ $\mathrm{PO}_{4}$ based on the average of the 10 lowest concentrations of $\mathrm{Ni}$ observed in this study), the ratios are slightly higher for the Antarctic origin deep water masses after all, and reasonably similar for SASPMW and NASPMW. Nevertheless, this does not explain the discrepancy between the slopes of the $\mathrm{Ni}-\mathrm{PO}_{4}$ relationship observed within the (Sub)Antarctic Ocean proper (Ellwood, 2008; Butler et al., 2013; Cloete et al., 2019) and along the current transect in Antarctic origin water masses. However, both Butler et al. (2013) and Ellwood (2008) focused on the upper water column of the SubAntartic Zone (SAZ) in the Pacific Section of the Southern Ocean, where mode water is formed, but this is north of the formation region of AAIW in the Polar Frontal Zone (PFZ). Cloete et al. (2019) report data for a station near the location of the Polar Front (PF) and the Sub Antarctic Front (SAF), but not in the PFZ either. Combining the $\mathrm{Ni}$ data reported by Lai et al. (2008) with the associated $\mathrm{PO}_{4}$ for the upper water column (upper $300 \mathrm{~m}$ ) [provided by Prof. Y. Sohrin (Kyoto University) and Prof. A. Bowie (University of Tasmania)], indeed the steepest slope $\left(\sim 4.94 \mathrm{nmol} \mu \mathrm{mol}^{-1}\right)$ is found for a station in summer in the PFZ, whereas less steep slopes are observed to the north and south, implying relatively high Ni uptake in the PFZ. However, this is based on a single station and, in contrast, a very gentle slope is found in the PFZ in spring over the Kerguelen plateau (Wang et al., 2019). Cloete et al. (2019) also report an elevated $\mathrm{Ni}: \mathrm{PO}_{4}$ uptake ratio

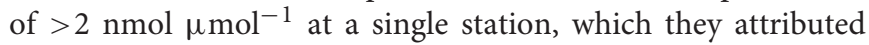
to increased metal uptake by diatoms, but lower uptake ratios at other stations. Clearly, additional detailed and full depth observations traversing the regions of formation of the various Southern Ocean water masses are needed to figure out whether the Ni-PO $\mathrm{P}_{4}$ relationship slopes as observed along the GA02 transect for Antarctic origin water masses are representative of the uptake and remineralization ratio in the source region, or whether this relatively steep slope is primarily the result of mixing during advection into the Atlantic Ocean.

\section{Similarities and Differences With Zn and $\mathbf{C d}$}

The main findings of the better studied cycles and distributions of $\mathrm{Zn}$ and $\mathrm{Cd}$ in the Atlantic and its source waters will be summarized here and compared to Ni (Figure 7). Previously it was shown that SASPMW is depleted in $\mathrm{Zn}$ (Middag et al., 2019) but not in Cd (Middag et al., 2018) and this was related to the depletion of $\mathrm{Zn}$ (and $\mathrm{Si}$ ) that starts already far south in the region of formation of AAIW, whereas $\mathrm{Cd}\left(\right.$ and $\left.\mathrm{PO}_{4}\right)$ are depleted further north. Briefly, uCDW upwells in the far south and advects northward toward the Polar Front (PF). During this northward advection toward the PF, $\mathrm{Zn}$ and $\mathrm{Si}$ concentrations decrease appreciably whereas $\mathrm{PO}_{4}$ and $\mathrm{Cd}$ concentrations remain relatively constant (e.g. Lancelot et al., 2000; Croot et al., 2011; Abouchami et al., 2014; Baars et al., 2014; Zhao et al., 2014), decreasing the dissolved $\mathrm{Zn} / \mathrm{PO}_{4}$ ratio in the surface layer. North of the PF in the formation region of AAIW (PFZ), also the $\mathrm{Cd}$ and $\mathrm{PO}_{4}$ concentrations start to decrease due to biological uptake where $\mathrm{Cd}$ is depleted faster than $\mathrm{PO}_{4}$, leading to a lower dissolved $\mathrm{Cd} / \mathrm{PO}_{4}$ ratio in the newly forming AAIW. However, given that depletion of $\mathrm{Zn}$ started further south, the effect is stronger on the $\mathrm{Zn} / \mathrm{PO}_{4}$ ratio and by the time the SAF is traversed, the $\mathrm{Zn}$ and $\mathrm{Si}$ concentrations are quite low $\left(<0.5 \mathrm{nmol} \mathrm{kg}{ }^{-1}\right.$ and $<2 \mu \mathrm{mol} \mathrm{kg}-1$, respectively). No detailed high resolution data for dissolved $\mathrm{Ni}$ is available for the Atlantic sector of the Southern Ocean traversing the PFZ and SAZ into the Atlantic Ocean. However, given the dominance of diatoms in the PFZ where $\mathrm{Si}$ is depleted (e.g. Quéguiner et al., 1997) and the relatively high Ni requirement of diatoms (Twining et al., 2012; Twining and Baines, 2013), it is likely there is significant Ni uptake as well, as was indeed observed in the PFZ in the Indian sector of the Southern Ocean (Lai et al., 2008). Relatively high Ni uptake by diatoms would lead to an elevated $\mathrm{Ni}: \mathrm{PO}_{4}$ uptake ratio in forming AAIW. Such uptake would decrease the dissolved $\mathrm{Ni} / \mathrm{PO}_{4}$ ratio in forming AAIW if the formed biomass is partly exported and remineralized in underlying water masses. In summary, newly forming AAIW should have intermediate $\mathrm{Ni}, \mathrm{Cd}$ and $\mathrm{PO}_{4}$ concentrations and a Ni/ $\mathrm{PO}_{4}$ ratio and $\mathrm{Cd} / \mathrm{PO}_{4}$ ratio that is lower than deep waters (Figure 7). Additionally, this forming AAIW has a relatively low $\mathrm{Zn}$ and $\mathrm{Si}$ concentration and a low $\mathrm{Zn} / \mathrm{PO}_{4}$ ratio compared to underlying water masses (Figure 7).

North of the SAF in the formation region of SASPMW (SAZ), the low abundance of diatoms due to the depletion of $\mathrm{Si}$ (e.g. Quéguiner et al., 1997), is expected to lead to surface waters with a comparatively high $\mathrm{Ni} / \mathrm{PO}_{4}$ dissolved ratio due to a presumed lower Ni: $\mathrm{PO}_{4}$ uptake ratio of the non-diatom community. In addition, uptake of $\mathrm{Cd}$ and $\mathrm{PO}_{4}$ accelerates, resulting in surface concentrations that decrease in a northward direction where $\mathrm{Cd}$ is depleted before $\mathrm{PO}_{4}$ (i.e. a relatively high Cd: $\mathrm{PO}_{4}$ uptake ratio). This decreases the remaining dissolved $\mathrm{Cd} / \mathrm{PO}_{4}$ ratio in forming SASPMW, but at the same time, regeneration of exported material increases both the concentrations as well as the $\mathrm{Cd} / \mathrm{PO}_{4}$ ratio in underlying AAIW. In contrast, the $\mathrm{Zn}$ and $\mathrm{Ni}$ concentrations are barely affected by this regeneration whereas the dissolved $\mathrm{Zn} / \mathrm{PO}_{4}$ and $\mathrm{Ni} / \mathrm{PO}_{4}$ ratios in the underlying AAIW decrease as a consequence of the lower uptake ratio in surface waters in the absence of diatoms. Overall, the $\mathrm{Ni} / \mathrm{PO}_{4}$ ratio is relatively high in SASPMW (Table 2), probably because the $\mathrm{Ni}$ stock in the formation region is only partly depleted with a relatively low Ni: $\mathrm{PO}_{4}$ uptake ratio. In contrast, the SASPMW has the lowest $\mathrm{Zn} / \mathrm{PO}_{4}$ ratio and $\mathrm{Cd} / \mathrm{PO}_{4}$ ratio of the southern origin water masses (Table 2). The ratio is most skewed for $\mathrm{Zn}$, as $\mathrm{Zn}$ was depleted before the formation region of SASPMW was reached, whereas $\mathrm{Cd}$ was depleted later along the northward advection path. The $\mathrm{Ni} / \mathrm{PO}_{4}$ ratio in forming AAIW is expected to be relatively low due to a relatively high uptake ratio and the ratio would further decrease due to remineralization of biogenic material from the SAZ (Figure 7 and Table 2). Similarly, AAIW also has a low $\mathrm{Zn} / \mathrm{PO}_{4}$ ratio compared to underlying water masses 


\section{Latitude}

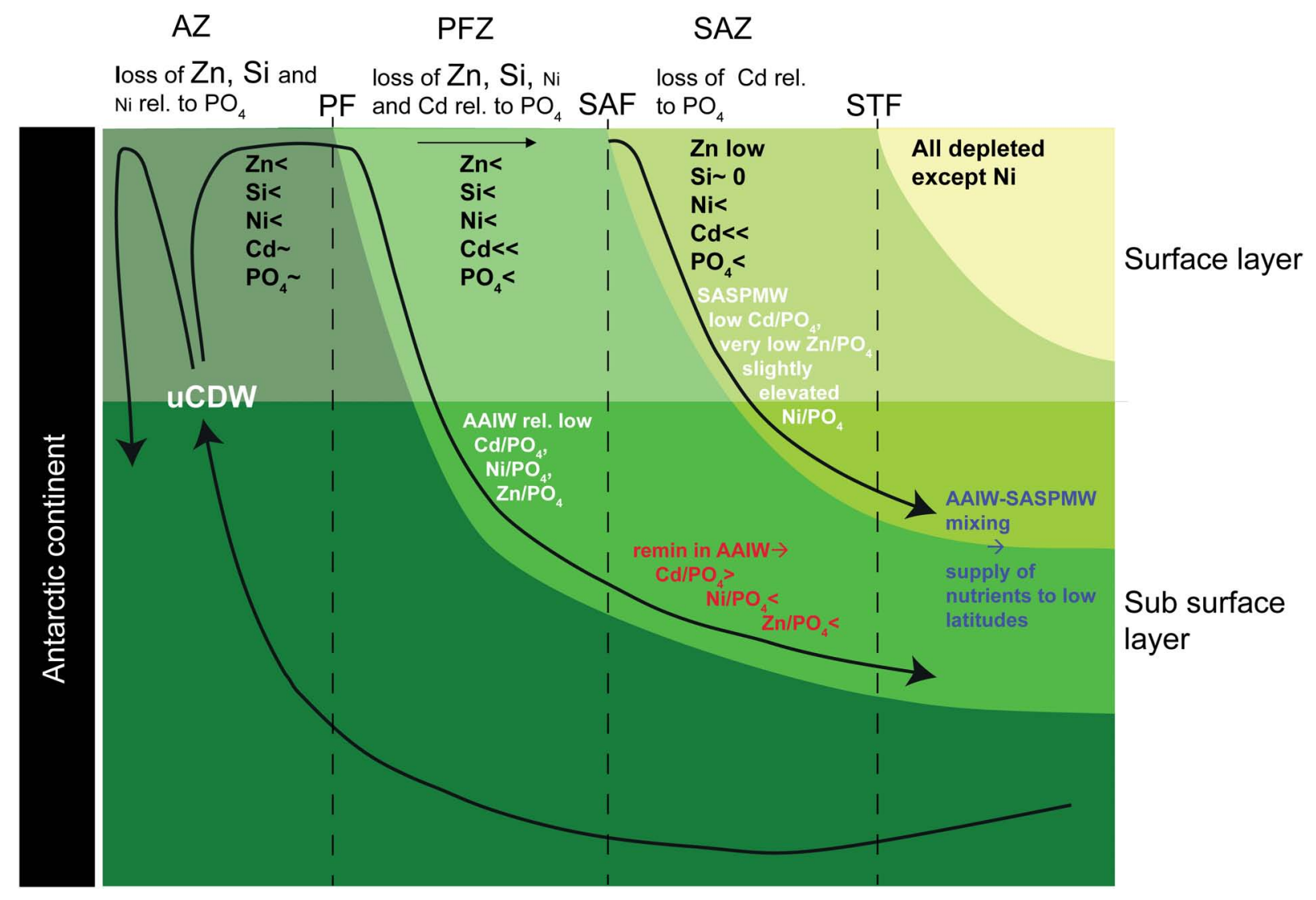

FIGURE 7 | Conceptual model of trace metal uptake and export in the Southern Ocean and the influence on the Metal/PO 4 ratio of the Antarctic origin water masses. The uptake of the various nutrients is indicated for the surface layer in the different latitudinal zones (<denotes uptake, $\sim$ denotes no or limited uptake, $<<$ denotes rapid depletion). Additionally, effects on the Metal/PO 4 ratios due to uptake and remineralization are indicated for the AAIW and SASPMW that play an important role in supplying nutrients to the Atlantic Ocean. This figure was inspired by the figure by Sarmiento et al. (2004); their Figure 4.

(Table 2). In contrast, the $\mathrm{Cd} / \mathrm{PO}_{4}$ ratio in AAIW is slightly lower than in underlying water masses (Table 2) but still relatively high due to regeneration of biogenic material with a high $\mathrm{Cd}: \mathrm{PO}_{4}$ ratio formed in the SAZ.

These southern signatures are subsequently transported to the North Atlantic where the mixture of SASPMW and AAIW has a strong influence on the supply ratio to the surface ocean. This mixture supplies both $\mathrm{Ni}, \mathrm{Cd}$, and $\mathrm{PO}_{4}$, but very little $\mathrm{Zn}$ and $\mathrm{Si}$, generating stark contrast between the near surface $\mathrm{Zn}-\mathrm{PO}_{4}$ relationship compared to the Ni- $\mathrm{PO}_{4}$ and $\mathrm{Cd}$ $\mathrm{PO}_{4}$ and relationships (Middag et al., 2019). The influence of uptake and remineralization in the southern formation regions for $\mathrm{Ni}$ is relatively modest compared to $\mathrm{Zn}$ and $\mathrm{Cd}$. If one assumes the composition of $\mathrm{uCDW}$ is representative for the supply to Southern Ocean surface water, the $\mathrm{Zn}$ concentration in AAIW is $76 \%$ depleted, the Cd concentration 35\% depleted and the Ni concentration 23\% depleted (Table 2). Comparing SASPMW to AAIW the depletions are $99 \%$ and $86 \%$ for $\mathrm{Zn}$ and $\mathrm{Cd}$, but only $33 \%$ for Ni (Table 2 ). As detailed above, due to dominance of diatoms in the formation region of AAIW and dominance of non-diatoms in the formation region of
SASPMW, the Ni:PO 4 uptake ratio is likely slightly higher in the former compared to the latter. This leads to a slightly lower dissolved ratio in forming AAIW compared to SASPMW and remineralization of biogenic particles is suggested to add to this effect. Strikingly, even though the Southern Ocean latitudinal uptake pattern of $\mathrm{Ni}$ seems more similar to that of $\mathrm{Zn}$ with uptake that starts far south due to the influence of diatoms, the mere partial depletion of $\mathrm{Ni}$ leads to an export signature that is more similar to $\mathrm{Cd}$ for which most depletion occurs north of the SAF. Thus despite the similarities in the gradients of $\mathrm{Ni}$ and $\mathrm{Cd}$ in the Atlantic Ocean (i.e. trends of increasing and decreasing concentrations between water masses), the underlying processes responsible for the concentration distribution appear quite different for these metals.

Besides the high latitude southern origin water masses, also the high latitude northern origin water masses play an important role in the distribution of elements in the Atlantic Ocean. For Ni, the $\mathrm{Ni} / \mathrm{PO}_{4}$ ratio is reasonably similar in NASPMW and SASPMW, as are the Ni concentrations (Table 2). However, the mixing of SASPWM with AAIW that has a relatively high Ni concentration and low $\mathrm{Ni} / \mathrm{PO}_{4}$ ratio, results in a ratio below the thermocline 
that seems to be slightly lower in the $\mathrm{SH}$ then the NH (Table 2). This was also observed for the $\mathrm{Zn} / \mathrm{PO}_{4}$ ratio at the same depth that is also lower in the $\mathrm{SH}$ compared to the $\mathrm{NH}$ (Middag et al., 2019), whereas the $\mathrm{Cd} / \mathrm{PO}_{4}$ ratio was higher in the subsurface $\mathrm{SH}$ compared to the NH (Middag et al., 2018). Overall, based on the better correlation between $\mathrm{Ni}$ and $\mathrm{Cd}$ (Figure 4B) than $\mathrm{Ni}$ and $\mathrm{Zn}$ (Figure 4D) one would expect the biogeochemical cycle of $\mathrm{Ni}$ to be most similar to the cycle of $\mathrm{Cd}$, but it appears the biogeochemical cycle of $\mathrm{Ni}$ shows some striking similarities with the cyle of $\mathrm{Zn}$ as well.

\section{CONCLUSION}

The Atlantic Ni- $\mathrm{PO}_{4}$ relationship is not well fitted by a single or bilinear regression. As previously demonstrated for Cd and $\mathrm{Zn}$ (Middag et al., 2018, 2019), the $\mathrm{Ni}$ distribution is governed by mixing of water masses with various origins and various endmember compositions and as such, multiple distinct regressions can be fitted. Regional remineralization (i.e. within the Atlantic) has a significant influence on the $\mathrm{PO}_{4}$ and $\mathrm{Cd}$ distribution whereas the influence on the distribution of $\mathrm{Ni}$ (like for $\mathrm{Zn}$ ) is much smaller with calculated contributions of remineralization of $\sim 50 \%, 30 \%, 13 \%$, and $6 \%$ of the maximum observed concentrations for $\mathrm{PO}_{4}, \mathrm{Cd}, \mathrm{Ni}$, and $\mathrm{Zn}$, respectively. This does not imply biogeochemical processes do not exert a strong influence on the distribution of $\mathrm{Ni}$ globally, as it is the biological uptake and remineralization of $\mathrm{Ni}$ that is responsible for the nutrient type profile of $\mathrm{Ni}$. However, specifically in the Atlantic, where Antarctic origin water masses with high concentrations of $\mathrm{Ni}$ mix with water masses of Nordic origin with a much lower concentration of $\mathrm{Ni}$, the mixing is the dominant control on the distribution of Ni. Additionally, the presumably low availability of $\mathrm{Ni}$ in the surface ocean might play a role in the relatively modest remineralization signature.

It is demonstrated here once again that the slope of a regression over the water column or the dissolved spot ratio should not be interpreted as representative of an uptake or remineralization ratio without careful consideration of the influence of mixing of water masses and the endmember compositions of these water masses. The highest concentrations of $\mathrm{Ni}$ are observed in the water masses of Antarctic origin, where $\mathrm{Ni}$ follows a pattern similar to $\mathrm{Cd}$ with the highest concentrations in $\mathrm{AABW}$ and $\mathrm{uCDW}$, and concentrations $\sim 25 \%$ lower in AAIW. In contrast to $\mathrm{Cd}, \mathrm{Ni}$ is depleted to only $50 \%$ of the maximum observed concentrations in SASPMW. The depletion pattern of $\mathrm{Ni}$ in the source regions of the Antarctic origin water masses is suggested to be more similar to $\mathrm{Zn}$ than $\mathrm{Cd}$. In the far south, $\mathrm{Ni}$ follows the pattern of $\mathrm{Zn}$ due to the higher $\mathrm{Ni}$ requirement of diatoms, but the $\mathrm{Zn}$ stock is depleted to a much further extend than Ni. Going northward, concentrations of $\mathrm{Ni}$ are much less depleted than both $\mathrm{Cd}$ and $\mathrm{Zn}$ in forming SASPMW due to differences in relative amounts of utilization. The concentration of Ni in AAIW is thought to be mainly the result of incomplete utilization in the formation region with a small influence of remineralization.
Despite the different uptake pattern in the Southern Ocean for $\mathrm{Ni}$ and $\mathrm{Cd}$, the trends of increasing and decreasing concentrations between water masses in the Atlantic are similar for these metals, even though there is an order of magnitude difference in actual concentrations. However, the gradients in the ratios of $\mathrm{Ni}$ and $\mathrm{Cd}$ with respect to $\mathrm{PO}_{4}$ are different; e.g. the $\mathrm{Ni} / \mathrm{PO}_{4}$ ratio is high in SASPMW compared to underlying water masses whereas the $\mathrm{Cd} / \mathrm{PO}_{4}$ ratio is low with respect to underlying water masses.

As both $\mathrm{NH}$ and $\mathrm{SH}$ subsurface water masses are elevated in $\mathrm{Ni}$ with respect to surface waters, supply of $\mathrm{Ni}$ to the surface layer of the subtropical gyres should be relatively high as well. Indeed the surface concentrations of $\mathrm{Ni}$ are rarely below $2 \mathrm{nmol} \mathrm{kg}^{-1}$, but this might also be related to limited bioavailability of the $\mathrm{Ni}$ pool for phytoplankton, as fully depleted Ni concentrations have not been observed in the surface ocean. Surface concentrations of $\mathrm{Ni}$ are lowest in the $\mathrm{NH}$ and correspond with known regions of high Fe deposition and nitrogen fixation. As nitrogen fixers can have a higher requirement for $\mathrm{Ni}$ due the $\mathrm{NiFe}$-hydrogenase enzyme and a $\mathrm{Ni}$ based SOD, it is suggested that enhanced uptake of $\mathrm{Ni}$ by these organisms could have a strong influence on the surface ocean distribution of $\mathrm{Ni}$.

Future research should be targeted at understanding the bio-availability of dissolved $\mathrm{Ni}$ to marine primary producers, including diazotrophs. Both the Antarctic and Nordic origin water masses play an important role in the supply of $\mathrm{Ni}$ as well as the ratio of $\mathrm{Ni}$ with respect to other nutrients. To better understand what is driving the Ni distribution in the Atlantic Ocean and how sensitive this distribution is to changes, detailed and full depth observations in the formation region of these water masses are needed.

\section{DATA AVAILABILITY STATEMENT}

All data reported in this paper is available through the GEOTRACES data repository (http://geotraces.org/dp/idp2017) at the British Oceanographic Data Centre as detailed by Schlitzer et al. (2018).

\section{AUTHOR CONTRIBUTIONS}

RM performed the sampling and analysis and led the data interpretations. $\mathrm{HB}$ organized the cruises and funding support and contributed in the interpretations. KB led the analysis. $\mathrm{SH}$ contributed to the eOMP analysis and interpretations.

\section{FUNDING}

This work was supported by the Netherlands Organization for Scientific Research (NWO) project grants 820.01.014 (GEOTRACES Netherlands-USA Joint Effort on Trace Metals in the Atlantic Ocean; post-doc of RM at UCSC) and 839.08.410 (GEOTRACES, Global Change and Microbial Oceanography in the West Atlantic Ocean) and the USA National Science Foundation (NSF) grant: OCE-0961579. 


\section{ACKNOWLEDGMENTS}

We are grateful to the captains and crew of the RV Pelagia and RRS James Cook for their support during the cruises. The nutrient data were provided by the NIOZ nutrient laboratory and the oxygen data by Lesley Salt and Maaike Claus (NIOZ). Prof. Y. Sohrin (Kyoto University) and Prof. A. Bowie (University of Tasmania) kindly shared the corresponding $\mathrm{PO}_{4}$ data for

\section{REFERENCES}

Abouchami, W., Galer, S. J. G., de Baar, H. J. W., Middag, R., Vance, D., Zhao, Y., et al. (2014). Biogeochemical cycling of cadmium isotopes in the Southern Ocean along the Zero Meridian. Geochim. Cosmochim. Acta 127, 348-367. doi: 10.1016/j.gca.2013.10.022

Baars, O., Abouchami, W., Galer, S. J. G., Boye, M., and Croot, P. L. (2014). Dissolved cadmium in the Southern Ocean: distribution, speciation, and relation to phosphate. Limnol. Oceanogr. 59, 385-399. doi: 10.4319/lo.2014.59. 2.0385

Benavides, M., and Voss, M. (2015). Five decades of N2 fixation research in the North Atlantic Ocean. Front. Mar. Sci. 2:40. doi: 10.3389/fmars.2015.00040

Biller, D. V., and Bruland, K. W. (2012). Analysis of Mn, Fe, Co, Ni, Cu, Zn, $\mathrm{Cd}$, and $\mathrm{Pb}$ in seawater using the Nobias-chelate $\mathrm{PA} 1$ resin and magnetic sector inductively coupled plasma mass spectrometry (ICP-MS). Mar. Chem. 13, 12-20. doi: 10.1016/j.marchem.2011.12.001

Bowie, A. R., Whitworth, D. J., Achterberg, E. P., Mantoura, R. F. C., and Worsfold, P. J. (2002). Biogeochemistry of Fe and other trace elements ( $\mathrm{Al}, \mathrm{Co}, \mathrm{Ni}$ ) in the upper Atlantic Ocean. Deep Sea Res. I Oceanogr. Res. Pap. 49, 605-636. doi: 10.1016/s0967-0637(01)00061-9

Bown, J., Laan, P., Ossebaar, S., Bakker, K., Rozema, P., and de Baar, H. J. W. (2017). Bioactive trace metal time series during Austral summer in Ryder Bay, Western Antarctic Peninsula. Deep Sea Res. II Top. Stud. Oceanogr. 139, 103-119. doi: 10.1016/j.dsr2.2016.07.004

Bruland, K. W. (1980). Oceanographic distributions of cadmium, zinc, nickel, and copper in the North Pacific. Earth Planet. Sci. Lett. 47, 176-198. doi: $10.1016 / 0012-821 \times(80) 90035-7$

Butler, E. C. V., O’Sullivan, J. E., Watson, R. J., Bowie, A. R., Remenyi, T. A., and Lannuzel, D. (2013). Trace metals $\mathrm{Cd}, \mathrm{Co}, \mathrm{Cu}, \mathrm{Ni}$, and $\mathrm{Zn}$ in waters of the subantarctic and Polar frontal zones south of Tasmania during the 'SAZ-Sense' project. Mar. Chem. 148, 63-76. doi: 10.1016/j.marchem.2012.10.005

Cameron, V., and Vance, D. (2014). Heavy nickel isotope compositions in rivers and the oceans. Geochim. Cosmochim. Acta 128, 195-211. doi: 10.1016/j.gca. 2013.12.007

Cid, A., Nakatsuka, S., and Sohrin, Y. (2012). Stoichiometry among bioactive trace metals in the Chukchi and Beaufort Seas. J. Oceanogr. 68, 985-1001. doi: 10.1007/s10872-012-0150-8

Cloete, R., Loock, J. C., Mtshali, T., Fietz, S., and Roychoudhury, A. N. (2019). Winter and summer distributions of Copper, Zinc and Nickel along the International GEOTRACES Section GIPY05: insights into deep winter mixing. Chem. Geol. 511, 342-357. doi: 10.1016/j.chemgeo.2018.10.023

Croot, P. L., Baars, O., and Streu, P. (2011). The distribution of dissolved zinc in the Atlantic sector of the Southern Ocean. Deep Sea Res. II Top. Stud. Oceanogr. 58, 2707-2719. doi: 10.1016/j.dsr2.2010.10.041

Cullen, J. T. (2006). On the nonlinear relationship between dissolved cadmium and phosphate in the modern global ocean: could chronic iron limitation of phytoplankton growth cause the kink? Limnol. Oceanogr. 51, 1369-1380. doi: 10.4319/lo.2006.51.3.1369

Danielsson, L.-G., Magnusson, B., and Westerlund, S. (1985). Cadmium, copper, iron, nickel and zinc in the north-east Atlantic Ocean. Mar. Chem. 17, 23-41. doi: 10.1016/0304-4203(85)90034-9

Danielsson, L.-G., and Westerlund, S. (1983). "Trace Metals in the Arctic Ocean," in Trace Metals in Sea Water, eds C. S. Wong, E. Boyle, K. W. Bruland, J. D. Burton, and E. D. Goldberg (Boston, MA: Springer), 85-95. doi: 10.1007/9781-4757-6864-0_5 their Ni data from the Southern Ocean (Lai et al., 2008). Loes Gerringa (NIOZ) and Erin Bertrand (Dalhousie University) are acknowledged for the useful discussions during the writing of this manuscript and the reviewers are acknowledged for their time and effort that improved the manuscript. Figures were made using ODV (Schlitzer, 2018) with the exception of Figure 7 that was made with the assistance of Nelleke Krijgsman (NIOZ).

De Baar, H. J. W., Timmermans, K. R., Laan, P., De Porto, H. H., Ober, S., Blom, J. J., et al. (2008). Titan: a new facility for ultraclean sampling of trace elements and isotopes in the deep oceans in the international Geotraces program. Mar. Chem. 111, 4-21. doi: 10.1016/j.marchem.2007.07.009

De Baar, H. J. W., van Heuven, S. M. A. C., and Middag, R. (2018). "Ocean biochemical cycling and trace elements," in Encyclopedia of Geochemistry: A Comprehensive Reference Source on the Chemistry of the Earth, ed. W. M. White (Cham: Springer International Publishing), 1-21. doi: 10.1007/978-3319-39193-9_356-1

Dupont, C. L., Barbeau, K., and Palenik, B. (2008). Ni uptake and limitation in marine Synechococcus strains. Appl. Environ. Microbiol. 74, 23-31. doi: 10.1128/ aem.01007-07

Dupont, C. L., Buck, K. N., Palenik, B., and Barbeau, K. (2010). Nickel utilization in phytoplankton assemblages from contrasting oceanic regimes. Deep Sea Res. I Oceanogr. Res. Pap. 57, 553-566. doi: 10.1016/j.dsr.2009.12.014

Egleston, E. S., and Morel, F. M. M. (2008). Nickel limitation and zinc toxicity in a urea-grown diatom. Limnol. Oceanogr. 53, 2462-2471. doi: 10.4319/lo.2008.53. 6.2462

Ellwood, M. J. (2008). Wintertime trace metal ( $\mathrm{Zn}, \mathrm{Cu}, \mathrm{Ni}, \mathrm{Cd}, \mathrm{Pb}$ and $\mathrm{Co}$ ) and nutrient distributions in the Subantarctic Zone between 40-52 degrees S; 155-160 degrees E. Mar. Chem. 112, 107-117. doi: 10.1016/j.marchem.2008.0 7.008

Fishwick, M. P., Sedwick, P. N., Lohan, M. C., Worsfold, P. J., Buck, K. N., Church, T. M., et al. (2014). The impact of changing surface ocean conditions on the dissolution of aerosol iron. Glob. Biogeochem. Cycles 28, 1235-1250. doi: 10.1002/2014gb004921

Flombaum, P., Gallegos, J. L., Gordillo, R. A., Rincón, J., Zabala, L. L., Jiao, N., et al. (2013). Present and future global distributions of the marine Cyanobacteria Prochlorococcus and Synechococcus. Proc. Natl. Acad. Sci. U.S.A. 110, 98249829. doi: 10.1073/pnas.1307701110

Gao, Y., Kaufman, Y. J., Tanre, D., Kolber, D., and Falkowski, P. G. (2001). Seasonal distributions of aeolian iron fluxes to the global ocean. Geophys. Res. Lett. 28, 29-32. doi: 10.1029/2000gl011926

Gerringa, L., Laan, P., and Middag, R. (unpublished). Data from German/Dutch Arctic GEOTRACES cruise.

Herut, B., Rahav, E., Tsagaraki, T. M., Giannakourou, A., Tsiola, A., Psarra, S., et al. (2016). The potential impact of saharan dust and polluted aerosols on microbial populations in the East Mediterranean Sea, an overview of a mesocosm experimental approach. Front. Mar. Sci. 3:226. doi: 10.3389/fmars. 2016.00226

Ho, T.-Y. (2013). Nickel limitation of nitrogen fixation in Trichodesmium. Limnol. Oceanogr. 58, 112-120. doi: 10.4319/lo.2013.58.1.0112

Ho, T.-Y., Chu, T.-H., and Hu, C.-L. (2013). Interrelated influence of light and Ni on Trichodesmium growth. Front. Microbiol. 4:139. doi: 10.3389/fmicb.2013. 00139

Jackson, S. L., Spence, J., Janssen, D. J., Ross, A. R. S., and Cullen, J. T. (2018). Determination of $\mathrm{Mn}, \mathrm{Fe}, \mathrm{Ni}, \mathrm{Cu}, \mathrm{Zn}, \mathrm{Cd}$ and $\mathrm{Pb}$ in seawater using offline extraction and triple quadrupole ICP-MS/MS. J. Analyt. Atom. Spectrom. 33, 304-313. doi: 10.1039/C7JA00237H

Jickells, T. D., and Burton, J. D. (1988). Cobalt, copper, manganese and nickel in the Sargasso Sea. Mar. Chem. 23, 131-144. doi: 10.3389/fmicb.2012.00359

Kondo, Y., Obata, H., Hioki, N., Ooki, A., Nishino, S., Kikuchi, T., et al. (2016). Transport of trace metals ( $\mathrm{Mn}, \mathrm{Fe}, \mathrm{Ni}, \mathrm{Zn}$ and $\mathrm{Cd}$ ) in the western Arctic Ocean (Chukchi Sea and Canada Basin) in late summer 2012. Deep Sea Res. I Oceanogr. Res. Pap. 116, 236-252. doi: 10.1016/j.dsr.2016.08.010 
Lagerström, M. E., Field, M. P., Séguret, M., Fischer, L., Hann, S., and Sherrell, R. M. (2013). Automated on-line flow-injection ICP-MS determination of trace metals $(\mathrm{Mn}, \mathrm{Fe}, \mathrm{Co}, \mathrm{Ni}, \mathrm{Cu}$ and $\mathrm{Zn}$ ) in open ocean seawater: application to the GEOTRACES program. Mar. Chem. 155, 71-80. doi: 10.1016/j.marchem.2013. 06.001

Lai, X., Norisuye, K., Mikata, M., Minami, T., Bowie, A. R., and Sohrin, Y. (2008). Spatial and temporal distribution of $\mathrm{Fe}, \mathrm{Ni}, \mathrm{Cu}$ and $\mathrm{Pb}$ along $140^{\circ} \mathrm{E}$ in the Southern Ocean during austral summer 2001/02. Mar. Chem. 111, 171-183. doi: 10.1016/j.marchem.2008.05.001

Lancelot, C., Hannon, E., Becquevort, S., Veth, C., and De Baar, H. J. W. (2000). Modeling phytoplankton blooms and carbon export production in the Southern Ocean: dominant controls by light and iron in the Atlantic sector in Austral spring 1992. Deep Sea Res. I Oceanogr. Res. Pap. 47, 1621-1662. doi: 10.1016/ s0967-0637(00)00005-4

Landing, W. M., Cutter, G. A., Dalziel, J. A., Flegal, A. R., Powell, R. T., Schmidt, D., et al. (1995). Analytical intercomparison results from the 1990 Intergovernmental Oceanographic Commission open-ocean baseline survey for trace metals: atlantic Ocean. Mar. Chem. 49, 253-265. doi: 10.1016/03044203(95)00016-k

Langlois, R. J., LaRoche, J., and Raab, P. A. (2005). Diazotrophic diversity and distribution in the tropical and subtropical Atlantic Ocean. Appl. Environ. Microbiol. 71, 7910-7919. doi: 10.1128/aem.71.12.7910-7919.2005

Mawji, E., Schlitzer, R., Dodas, E. M., Abadie, C., Abouchami, W., and Anderson, R. F. (2015). The GEOTRACES intermediate data product 2014. Mar. Chem. 177(Pt 1), 1-8.

Middag, R., de Baar, H. J. W., and Bruland, K. W. (2019). The relationships between dissolved Zinc and major nutrients Phosphate and Silicate along the GEOTRACES GA02 transect in the West Atlantic Ocean. Glob. Biogeochem. Cycles 33, 63-84. doi: 10.1029/2018gb006034

Middag, R., Séférian, R., Conway, T. M., John, S. G., Bruland, K. W., and de Baar, H. J. W. (2015a). Intercomparison of dissolved trace elements at the Bermuda Atlantic Time series station. Mar. Chem. 177(Pt 3), 476-489. doi: 10.1016/j. marchem.2015.06.014

Middag, R., van Heuven, S. M. A. C., Bruland, K. W., and de Baar, H. J. W. (2018). The relationship between cadmium and phosphate in the Atlantic Ocean unravelled. Earth Planet. Sci. Lett. 492, 79-88. doi: 10.1016/j.epsl.2018.03.046

Middag, R., van Hulten, M. M. P., Van Aken, H. M., Rijkenberg, M. J. A., Gerringa, L. J. A., Laan, P., et al. (2015b). Dissolved aluminium in the ocean conveyor of the West Atlantic Ocean: effects of the biological cycle, scavenging, sediment resuspension and hydrography. Mar. Chem. 177(Pt 1), 69-86. doi: 10.1016/j. marchem.2015.02.015

Middag, R., van Slooten, C., de Baar, H. J. W., and Laan, P. (2011). Dissolved aluminium in the Southern Ocean. Deep Sea Res. II Top. Stud. Oceanogr. 58, $2647-2660$.

Milne, A., Landing, W., Bizimis, M., and Morton, P. (2010). Determination of Mn, $\mathrm{Fe}, \mathrm{Co}, \mathrm{Ni}, \mathrm{Cu}, \mathrm{Zn}, \mathrm{Cd}$ and $\mathrm{Pb}$ in seawater using high resolution magnetic sector inductively coupled mass spectrometry (HR-ICP-MS). Analyt. Chim. Acta 665, 200-207. doi: 10.1016/j.aca.2010.03.027

Minami, T., Konagaya, W., Zheng, L., Takano, S., Sasaki, M., Murata, R., et al. (2015). An off-line automated preconcentration system with ethylenediaminetriacetate chelating resin for the determination of trace metals in seawater by high-resolution inductively coupled plasma mass spectrometry. Analyt. Chim. Acta 854, 183-190. doi: 10.1016/j.aca.2014.11.016

Morel, F. M. M., Hudson, R. J. M., and Price, N. M. (1991). Limitation of productivity by trace metals in the sea. Limnol. Oceanogr. 36, 1742-1755. doi: 10.4319/lo.1991.36.8.1742

Morel, F. M. M., Milligan, A. J., and Saito, M. A. (2014). "8.5 - marine bioinorganic chemistry: the role of trace metals in the oceanic cycles of major nutrients," in Treatise on Geochemistry (Second Edition), eds H. D. Holland, and K. K. Turekian (Oxford: Elsevier), 123-150. doi: 10.1016/b978-0-08-095975-7. 00605-7

Nimmo, M., van den Berg, C. M. G., and Brown, J. (1989). The chemical speciation of dissolved nickel, copper, vanadium and iron in Liverpool Bay. Irish Sea. Estuar. Coast. Shelf Sci. 29, 57-74. doi: 10.1016/0272-7714(89)900 73-5

Nuester, J., Vogt, S., Newville, M., Kustka, A., and Twining, B. (2012). The unique biogeochemical signature of the marine diazotroph Trichodesmium. Front. Microbiol. 3:150. doi: 10.3389/fmicb.2012.00150
Price, N. M., and Morel, F. M. M. (1991). Colimitation of phytoplankton growth by nickel and nitrogen. Limnol. Oceanogr. 36, 1071-1077. doi: 10.4319/lo.1991. 36.6.1071

Priya, B., Premanandh, J., Dhanalakshmi, R. T., Seethalakshmi, T., Uma, L., Prabaharan, D., et al. (2007). Comparative analysis of cyanobacterial superoxide dismutases to discriminate canonical forms. BMC Genomics 8:435. doi: 10.1186/ 1471-2164-8-435

Quéguiner, B., Tréguer, P., Peeken, I., and Scharek, R. (1997). Biogeochemical dynamics and the silicon cycle in the Atlantic sector of the Southern Ocean during austral spring 1992. Deep Sea Res. II Top. Stud. Oceanogr. 44, 69-89. doi: 10.1016/s0967-0645(96)00066-5

Quéroué, F., Townsend, A., van der Merwe, P., Lannuzel, D., Sarthou, G., Bucciarelli, E., et al. (2014). Advances in the offline trace metal extraction of Mn, $\mathrm{Co}, \mathrm{Ni}, \mathrm{Cu}, \mathrm{Cd}$, and $\mathrm{Pb}$ from open ocean seawater samples with determination by sector field ICP-MS analysis. Analyt. Methods 6, 2837-2847. doi: 10.1039/ c3ay $41312 \mathrm{~h}$

Rapp, I., Schlosser, C., Rusiecka, D., Gledhill, M., and Achterberg, E. P. (2017). Automated preconcentration of $\mathrm{Fe}, \mathrm{Zn}, \mathrm{Cu}, \mathrm{Ni}, \mathrm{Cd}, \mathrm{Pb}, \mathrm{Co}$, and $\mathrm{Mn}$ in seawater with analysis using high-resolution sector field inductively-coupled plasma mass spectrometry. Analyt. Chim. Acta 976, 1-13. doi: 10.1016/j.aca.2017.0 5.008

Rijkenberg, M. J. A., de Baar, H. J. W., Bakker, K., Gerringa, L. J. A., Keijzer, E., Laan, M., et al. (2015). "PRISTINE", a new high volume sampler for ultraclean sampling of trace metals and isotopes. Mar. Chem. 177(Pt 3), 501-509. doi: 10.1016/j.marchem.2015.07.001

Rijkenberg, M. J. A., Middag, R., Laan, P., Gerringa, L. J. A., van Aken, H. M., Schoemann, V., et al. (2014). The distribution of dissolved iron in the West Atlantic Ocean. PLoS One 9:e101323. doi: 10.1371/journal.pone.0101323

Rodriguez, I. B., and Ho, T.-Y. (2014). Diel nitrogen fixation pattern of Trichodesmium: the interactive control of light and Ni. Sci. Rep. 4:4445. doi: 10.1038/srep04445

Saager, P. M., de Baar, H. J. W., de Jong, J. T. M., Nolting, R. F., and Schijf, J. (1997). Hydrography and local sources of dissolved trace metals $\mathrm{Mn}, \mathrm{Ni}$, $\mathrm{Cu}$, and $\mathrm{Cd}$ in the northeast Atlantic Ocean. Mar. Chem. 57, 195-216. doi: 10.1016/s0304-4203(97)00038-8

Saito, M. A., Moffett, J. W., and DiTullio, G. R. (2004). Cobalt and nickel in the Peru upwelling region: a major flux of labile cobalt utilized as a micronutrient. Glob. Biogeochem. Cycles 18:GB4030.

Sarmiento, J. L., Gruber, N., Brzezinski, M. A., and Dunne, J. P. (2004). High-latitude controls of thermocline nutrients and low latitude biological productivity. Nature 427, 56-60. doi: 10.1038/nature02127

Schlitzer, R. (2018). Ocean Data View, Version 5.1.0. Available at: https://odv.awi.de Schlitzer, R., Anderson, R. F., Dodas, E. M., Lohan, M., Geibert, W., and Tagliabue, A. (2018). The GEOTRACES intermediate data product 2017. Chem. Geol. 493, 210-223.

Schlosser, C., Klar, J. K., Wake, B. D., Snow, J. T., Honey, D. J., Woodward, E. M. S., et al. (2014). Seasonal ITCZ migration dynamically controls the location of the (sub)tropical Atlantic biogeochemical divide. Proc. Natl. Acad. Sci. U.S.A. 111, 1438-1442. doi: 10.1073/pnas.1318670111

Sohrin, Y., Urushihara, S., Nakatsuka, S., Kono, T., Higo, E., Minami, T., et al. (2008). Multielemental determination of GEOTRACES key trace metals in Seawater by ICPMS after preconcentration using an ethylenediaminetriacetic acid chelating Resin. Anal. Chem. 80, 6267-6273. doi: 10.1021/ac800500f

Sunda, W. G., and Huntsman, S. A. (2000). Effect of Zn, Mn, and Fe on Cd accumulation in phytoplankton: implications for oceanic Cd cycling. Limnol. Oceanogr. 45, 1501-1516. doi: 10.4319/lo.2000.45.7.1501

Takano, S., Tanimizu, M., Hirata, T., Shin, K.-C., Fukami, Y., Suzuki, K., et al. (2017). A simple and rapid method for isotopic analysis of nickel, copper, and zinc in seawater using chelating extraction and anion exchange. Analyt. Chim. Acta 967, 1-11. doi: 10.1016/j.aca.2017.03.010

Tamagnini, P., Axelsson, R., Lindberg, P., Oxelfelt, F., Wünschiers, R., and Lindblad, P. (2002). Hydrogenases and hydrogen metabolism of Cyanobacteria. Microbiol. Mol. Biol. Rev. 66, 1-20. doi: 10.1128/mmbr.66.1.1-20.2002

Thi Dieu Vu, H., and Sohrin, Y. (2013). Diverse stoichiometry of dissolved trace metals in the Indian Ocean. Sci. Rep. 3:1745.

Tomczak, M. (1981). A multi-parameter extension of temperature/salinity diagram techniques for the analysis of non-isopycnal mixing. Prog. Oceanogr. 10, 147-171. doi: 10.1016/0079-6611(81)90010-0 
Tomczak, M. (1999). Some historical, theoretical and applied aspects of quantitative water mass analysis. J. Mar. Res. 57, 275-303. doi: 10.1357/ 002224099321618227

Twining, B. S., and Baines, S. B. (2013). The trace metal composition of marine Phytoplankton. Annu. Rev. Mar. Sci. 5, 191-215. doi: 10.1146/annurev-marine121211-172322

Twining, B. S., Baines, S. B., Vogt, S., and Nelson, D. M. (2012). Role of diatoms in nickel biogeochemistry in the ocean. Glob. Biogeochem. Cycles 26:GB4001.

Van Aken, H. M. (2007). The Oceanic Thermohaline Circulation: An Introduction. New York, NY: Springer Science + Business Media.

Van Den Berg, C. M. G., and Nimmo, M. (1987). Determination of interactions of nickel with dissolved organic material in seawater using cathodic stripping voltammetry. Sci. Total Environ. 60, 185-195. doi: 10.1016/0048-9697(87) 90415-3

Van Hulten, M., Middag, R., Dutay, J. C., De Baar, H., Roy-Barman, M., Gehlen, M., et al. (2017). Manganese in the west Atlantic Ocean in the context of the first global ocean circulation model of manganese. Biogeosciences 14, 1123-1152. doi: 10.5194/bg-14-1123-2017

Wang, R. M., Archer, C., Bowie, A. R., and Vance, D. (2019). Zinc and nickel isotopes in seawater from the Indian Sector of the Southern Ocean: the impact of natural iron fertilization versus Southern Ocean hydrography and biogeochemistry. Chem. Geol. 511, 452-464. doi: 10.1016/j.chemgeo.2018.0 9.010
Westerlund, S. F. G., Anderson, L. G., Hall, P. O. J., Iverfeldt, Å, Van Der Loeff, M. M. R., and Sundby, B. (1986). Benthic fluxes of cadmium, copper, nickel, zinc and lead in the coastal environment. Geochim. Cosmochim. Acta 50, 1289-1296. doi: 10.1016/0016-7037(86)904 12-6

Wuttig, K., Townsend, A. T., van der Merwe, P., Gault-Ringold, M., Holmes, T., Schallenberg, C., et al. (2019). Critical evaluation of a seaFAST system for the analysis of trace metals in marine samples. Talanta 197, 653-668. doi: 10.1016/ j.talanta.2019.01.047

Zhao, Y., Vance, D., Abouchami, W., and de Baar, H. J. W. (2014). Biogeochemical cycling of zinc and its isotopes in the Southern Ocean. Geochim. Cosmochim. Acta 125, 653-672. doi: 10.1111/gbi.12289

Conflict of Interest: The authors declare that the research was conducted in the absence of any commercial or financial relationships that could be construed as a potential conflict of interest.

Copyright (C) 2020 Middag, de Baar, Bruland and van Heuven. This is an open-access article distributed under the terms of the Creative Commons Attribution License (CC BY). The use, distribution or reproduction in other forums is permitted, provided the original author(s) and the copyright owner(s) are credited and that the original publication in this journal is cited, in accordance with accepted academic practice. No use, distribution or reproduction is permitted which does not comply with these terms. 